Columbia Law School

Scholarship Archive

1995

\title{
Girls and the Getaway: Cars, Culture, and the Predicament of Gendered Space
}

Carol Sanger

Columbia Law School, csanger@law.columbia.edu

Follow this and additional works at: https://scholarship.law.columbia.edu/faculty_scholarship

Part of the Law and Gender Commons, and the Law and Society Commons

\section{Recommended Citation}

Carol Sanger, Girls and the Getaway: Cars, Culture, and the Predicament of Gendered Space, 144 U. PA. L. REV. 705 (1995).

Available at: https://scholarship.law.columbia.edu/faculty_scholarship/1437

This Article is brought to you for free and open access by the Faculty Publications at Scholarship Archive. It has been accepted for inclusion in Faculty Scholarship by an authorized administrator of Scholarship Archive. For more information, please contact scholarshiparchive@law.columbia.edu, rwitt@law.columbia.edu. 


\title{
ESSAY
}

\section{GIRLS AND THE GETAWAY: GARS, CULTURE, AND THE PREDICAMENT OF GENDERED SPACE}

\author{
Garol SANGer $\dagger$
}

The auto is the link which binds the metropolis to my pastoral existence; which brings me into frequent touch with the entertainment and life of my neighboring small towns,-with the joys of bargain, library and soda-fountain.

Christine McGaffey Frederick (1912)

The People's theory is that the acts of sexual intercourse ... were the result of threats which could be implied from the circumstances. Central to that theory is the factor of the victim being inside a moving vehicle which was under the control of the defendant.

People v. Hunt (1977)

\section{INTRODUCTION}

What does law tell us about our relations to material things? Property theorists maintain that there are no legal relations between persons and things. ${ }^{3}$ Things can be owned, transferred, bequeathed, assigned, repossessed, and so on, but such arrangements really describe relationships among different persons with regard to the object rather than relationships between persons and things.

† Professor, Santa Clara University School of Law. I would like to thank Margalynne Armstrong, Ed Baker, June Carbone, Debra Livingston, and Jeremy Waldron for their comments on this Essay, Nancy Ota and Jessica Schaeztl for their research help, and Erik Bertin and Quang $\mathrm{Ha}$ for editing assistance. A version of this Essay was presented on March 31, 1995, as part of the conference on Women, Sexuality, and Violence: Revisioning Public Policy sponsored by the Annenberg Public Policy Center at the University of Pennsylvania.

${ }^{1}$ Christine M. Frederick, The Commuter's Wife and the Motor Car, 14 SUBURBAN LIFE 13, 13-14 (1912).

2139 Cal. Rptr. 675, 678 (Ct. App. 1977).

3 See Jeremy Waldron, The Right to Private Property 26-30 (1988). 
Yet the quality or shape of the legal relations among persons often depends on the cultural meaning of the thing in question, a meaning (or meanings) that exists, in some form anyway, prior to or independent of, legal concepts traditionally attached to things such as ownership or liability. Our legal relations with one another are informed by our social relations to things in that we relate to one another through (in, on, and around) things and not merely to things themselves.

What, then, is the legal significance of the social significance of things? How does the law comprehend, affect, reinforce, transform, and undermine the relations between persons and things? In this Essay I examine these questions by looking at connections between one particular thing-the automobile-and one particular group of persons-women. How it is that the automobile has come to serve women-as drivers, as passengers, as purchasers-less well than men? After all, in some sense a car is a gender neutral machine seemingly capable of taking drivers of either sex equal distances. But how long after the first one was welded together did it shed any pretense of such neutrality? How did that transformation come about and what has law made of the results?

The inquiry takes as a starting point the anthropologist's view that "things have no meanings apart from those that human transactions, attributions, and motivations endow them with." ${ }^{n 4}$ Indeed, for many anthropologists,

this formal truth does not illuminate the concrete, historical circulation of things. For that we have to follow the things themselves, for their meanings are inscribed in their forms, their uses, their trajectories. It is only through the analysis of these trajectories that we can interpret the human transactions and calculations that enliven things. ${ }^{5}$

Of course, the study of things is not limited to anthropologists. Commodities and things in general "constitute a topic of lively interest to social and economic historians, to art historians, and, lest we forget, to economists, though each discipline might constitute the problem differently." The same is true of legal scholars. The

- Arjun Appadurai, Introduction: Commodities and the Politics of Value, in THE Social life of Things: Commodities in Cultural Perspective 3, 5 (Arjun Appadurai ed., 1986).

${ }^{5}$ Id.

${ }^{6} I d$. 
more sophisticated investigations of property currently focus on the distinctive relationships between persons and objects. ${ }^{7}$

This Essay contributes to the project by looking at how the meaning and use of the automobile has become powerfully inscribed through law. My argument is that the car has sustained and enhanced traditional understandings about women's abilities and roles in areas both public (the road) and private (the driveway). Specifically, the car has reinforced women's subordinated status in ways that make the subordination seem ordinary, even logical through two predictable, but subtle, mechanisms: by increasing women's domestic obligations and by sexualizing the relation between women and cars.

The origins of this project lie somewhere between Dinah Shore and Thelma $\mathcal{E}^{2}$ Louise. ${ }^{8}$ Percolating in my subconscious has been the memory of Dinah Shore (circa 1950-something) with her bright red lips (apparent even on a black and white television) inviting me and my family to "See the USA in our Chevrolet" and reminding us, as she blew her huge farewell kiss, that "America is the Greatest Land of All." Thirty years later, the movie Thelma $\mathcal{E}^{2}$ Louise-which has its own share of beautiful red lips-told quite a different story about seeing "the Greatest Land of All" by car. As the two women try to drive from Oklahoma to Mexico without going through Texas, Louise explains to Thelma, "Look, you shoot off a guy's head with his pants down-believe me, Texas is not the place you want to get caught."

Louise's comment may be an extreme version of a fairly common understanding among women about not "getting caught" in the wrong place while driving. Young women are regularly warned never to drive on a low tank of gas or on bad tires. Recall the generic commercial with the woman driving down a dark, rainstreaked road, windshield wipers keeping pace with her accelerating heartbeat. Aren't you glad you bought her the Sears long-life?

Yet while one of the dangers which cars present for women is that they can take us too far from home and then break down, my focus here is not on mechanical difficulties. The perils for women of driving, buying, or riding in cars are more complicated and far less easy to fix. After all, it wasn't bad brake linings that sent Thelma and Louise over the edge.

7 See MARGaret J. RADIN, REINTERPRETING PROPERTY 37 (1993).

8 THELMA \& LOUISE (Metro-Goldwyn-Mayer 1991).

${ }^{9}$ Id. 
That is not to say that cars had nothing to do with their plunge. Thelma and Louise engaged in lots of questionable car-connected activities: they drove off alone, picked up a hitchhiker, defied the highway patrol, and, in a scene which for many women motorists depicted justice overdue, took on a harassing trucker and blew up his rig, nudie wheel flaps and all. Of course, Thelma and Louise paid for each of these decisions. Thelma was nearly raped in a parking lot; the hitchhiker stole their getaway money; the police, FBI, and SWAT teams of the entire Southwest apparently had no choice but to surround the two women in a dragnet from which there could be no escape. Indeed, from the moment the two women pulled away from Thelma's driveway, the movie, like their Thunderbird itself, speeds up so that Louise's final, suicidal acceleration is stunning but not unexpected.

My position here is not that driving for women equals death. Many of us drive regularly and regularly make it home. At the same time, I don't want to deny or minimize the dangers for women of driving cars, of giving people lifts, of accepting rides, of walking in parking lots, or of helping other motorists. ${ }^{10}$ But rather than simply flag these activities as dangerous, I want to consider them within a more systematic inquiry of how cars figure into women's lives and how law contributes to the arrangement.

The case I shall develop is this: From the start, the automobile has been presented as both the symbol and the means of women's liberation. Anyone who could turn a crank, or by the 1920 s just a key, could take off on her own. To a large extent, however, the exciting promise of driving, owning, or riding in a car comes to a crashing but often unmarked halt when played out in the context of women's lives. Get away, indeed! Thelma and Louise couldn't even make it to the border. What I want to think about here is why they couldn't. What assumptions do we bring to the idea of women and cars which so prepare us for the apparent inevitability of the film's final frame?

Certain subordinating connections come quickly to mind. The very phrase "women drivers" refers not to women who drive but absent-minded femmes at a loss behind the wheel of such a big machine. High school driver's-ed classes still show women drivers "as dreamy, air-headed yackers who are hopelessly ignorant about

${ }^{10}$ For a discussion of the pervasive violence against women in the context of cars and driving, see infra part II.B. 
the mechanical complexities of life." ${ }^{11}$ The use of women to sell cars is equally familiar. The tedious practice of draping women across car hoods at auto shows and the prominence of long-legged young women in car ads (now occasionally wearing very short business suits) remain successful marketing techniques. ${ }^{12}$

There may be nothing especially automotive about these examples. The sexual use of women in automotive advertisements (and the popularity of shop tools as common props in pornography) differs little from advertising strategies for other "male-dominant" products. ${ }^{13}$ Similarly, making fun of women who drive cars, fly planes, or participate in other activities tagged as male comes as no surprise.

What I want to explore here is not the use of women in car culture but rather how women use cars and what cultureparticularly law-has made of that. I approach the issue by considering cars in two different ways: cars as means and cars as places. I start with the car as a form of transportation. Despite the advertisers' promises of taking to the open road, for many women cars have served less as an escape from domestic duties than as a technologically enhanced form of domestic obligation. I develop this idea in Part I by looking at how suburban zoning ordinances helped rigidify gender roles, contributing to the creation of the modern chauffeur-mother, now tethered less to the hearth than to the garage.

Part II then shifts the focus from the car as a form of transportation-the means of getting us from here to there-to the car as a location-a place of private, intimate space. Many of us spend hours and hours in stationary cars: reading, working, drinking coffee in

"Driver Education Classes Reinforce Sexist Attitudes, SAN JOSE MERcury NEws, Mar. 27, 1992, at 4H; see also Michael L. Berger, Women Drivers!: The Emergence of Folklore and Stereotypic Opinions Concerning Feminine Automotive Behavior, 9 WOMEN's STUD. INT'L F. 257, 257-58 (1986) (suggesting that the invention of the category "women drivers" may have been a preemptive strike by men against signs of women's competence and independence evidently produced by their control of cars); Andrea Heiman, Beyond Thinking Pink, L.A. TIMES, June 2, 1992, at E1, E5 (noting that "[w]hen boys were busy bonding with their cars and studying the inner workings of motors, girls were being encouraged to find boyfriends with cars").

${ }^{12}$ See Heiman, supra note 11, at E5.

${ }^{13}$ See generally Joseph A. Bellizzi \& Laura Milner, Gender Positioning of a Traditionally Male-Dominant Product, J. ADVERTISING RES., June-July 1991, at 72, 72 (noting that "gender is still a key positioning variable in that efforts are made to show a particular gender as the typical user of that [particular] product"). 
solitude, talking with, or holding hands with someone else. As David Rieff writes in Los Angeles: Capital of the Third World:

If Southern California contains a world of dream houses, none are quite so dreamy in the end as that ultimate residence, the automobile. Was it the association of the idea of freedom ... with that of mobility that made the American love affair with the car persist long after traffic conditions had made the actual experience of driving anything but fun? Certainly, the promise of the automobile was not transportation so much as solitude and independence .... ${ }^{14}$

But imagining the car as a place of independence and solitude for women becomes more complicated when we consider the connections between cars and sex. The car itself-long, sleek, and powerful-has long been associated with sexuality. Consider Roland Barthes's description of the arrival of the new 1958 Citroën D.S.: "In the exhibition halls, the car on show is explored with an intense, amorous studiousness .... The bodywork, the lines of union are touched, the upholstery palpated, the seats tried, the doors caressed, the cushions fondled; before the wheel, one pretends to drive with one's whole body. ${ }^{15}$ At a less florid level, getting one's driver's license, borrowing keys, cruising, and making out have been accepted (or popularized) as rites of sexual passage, at least for boys, within American culture. ${ }^{16}$ Since its creation (or at least since the advent of closed sides and a covered roof), the car has

${ }^{14}$ DAvid Rieff, Los ANGeles: CAPITAL OF THE THIRD WORLd 45 (1991).

${ }^{15}$ ROLAND BARTHES, The New Citroën, in MYTHOLOGIES 88, 90 (Annette Lavers trans., 1972). For a splendid visual study of the sexuality of cars in and as art, see GILLES NERET \& HERVÉ POULAIN, L'ART, LA FEMME ET L'AUTOMOBILE (1989).

${ }^{16}$ See Mariamne H. Whatley, Raging Hormones and Powerful Cars: The Construction of Men's Sexuality in School Sex Education and Popular Adolescent Films, 179 B.U. J. EDUC. 100, 114-15 (1988). There may be a literary equivalent for post-adolescent authors as well. A review of five new "on-the-road" books (1990 versions of Kerouac) describes a formula featuring "a narrator using the internal combustion engine as Muse" and a "restless, mid-something male deciding he must go off alone in America driving his favorite stripped-down or optioned-up vehicle-generically, a 19-oughtsomething four-cylinder Testosterone will do, with a pint of Anomie stashed in the glove compartment ...." Francis X. Clines, They See America Rolling, N.Y. TIMES BOOK REV., May 9, 1993, at 1.

Driving is recognized not only as a marker of adulthood, but also as a measure of civic participation. Thus Connecticut's Department of Motor Vehicles runs a drivers' education program for license-less veterans. The license "is not seen as just a means toward greater mobility, and perhaps a job, but as a way to help restore some feeling of legitimacy for people who gave to their country but somehow ended up on the margins." Kirk Johnson, Driver's License Gives Veterans Lease on Life, N.Y. TIMES, May 31, 1993, at 28. 
been a place for courtship and for sex. Sometimes the two activities merge, but the legality of the merger hinges on the presence of the woman's consent. Without it we have kidnapping and rape.

And here traditional legal assumptions about consenting take on new meaning with regard to the "ultimate residence." Thus in Part II, I investigate the extent to which the law assumes that a woman who gets into a man's car or gives him a lift in hers also gives a proxy for consent to sex by looking at the role of cars in rape cases. I will focus on three much publicized trials from the early 1990s involving Mike Tyson, William Kennedy Smith, and five students from St. John's University.

\section{I. "FREEDOM FOR THE WOMAN WHO OWNS A FORD"17}

\section{A. Driving As Liberation}

While cars provided all early motorists with unimagined new freedom, the possibility of motor travel was particularly exhilarating for women. Before the car, women may have been at the same technological disadvantage as men, but their freedom of movement was additionally constrained by social convention. Victorian women and their early twentieth century successors may have been "angels in the house, ${ }^{18}$ but not anyplace else, especially not on the public street. ${ }^{19}$

The press of sweaty, male, working-class bodies made streetcars and trolleys unacceptable as an appropriate means of transportation for ladies. The Society for the Protection of Passenger Rights noted in 1907 that the New York City subway was "crowded to the point of indecency." 20 Racial prejudices added to the disagreeable character of public conveyances for white passengers. White men

${ }^{17}$ FORD ADVERTISEMENT (1915), reprinted in ANNE FORD \& CHARLOTTE FORD, HOW TO LOVE THE CAR IN YOUR LIFE 18 (1980).

${ }^{18}$ See generally BRAM DIJKSTRA, IDOLS OF PERVERSITY: FANTASIES OF FEMININE EVIL IN FIN-DE-SIĖCLE CULTURE 18, 19 (1986).

19 See LINDA GORDON, HEROES Of THEIR OWN LIVES: THE POLITICS AND HiSTORY OF FAMILY VIOLENCE 124-26 (1988) (noting that by the late 19th century, being on the street, or allowing one's children to be, was taken as a sign of deviance by middleclass social workers who supervised the lives of working class mothers); see also Christine STANSEll, CITY OF WOMEN: SEX AND ClASS IN NEW YORK, 1789-1860, at 213 (1987) (explaining that Victorian reformers like the Children's Aid Society recruited girls off the streets to teach them "the arts of plain sewing, cooking and housecleaning").

${ }^{20}$ VIRGINIA SCHARFF, TAKING THE WHEEL: WOMEN AND THE COMING OF THE MOTOR AGE 6 (1991). 
in Chicago objected to the idea of their wives and daughters riding on streetcars "breast to breast with Negroes." ${ }^{21}$ A 1912 article in the Los Angeles Record revealed similar concerns:

"Inside the air was a pestilence; it was heavy with disease and the emanations from many bodies. Anyone leaving this working mass, anyone coming into it ... forced the people into still closer, still more indecent, still more immoral contact .... Was this an oriental prison? Was this some hall devoted to the pleasures of the habitués of vice? No gentle reader, ... [i]t was a Los Angeles streetcar on the 9th day of December in the year of grace 1912. ${ }^{22}$

The private car insulated white riders from all the perceived dangers of public association.

A more vivid set of dangers confronted black passengers on public trolleys and buses. African-Americans in the South suffered under segregated streetcar systems, enduring the daily insult of rude treatment and poor service. Women were especially subjected to harassment by white bus drivers and white passengers. ${ }^{23}$ A 1921 article in the black newspaper The Independent bluntly made the case for private transportation: "Buy a car of your own and escape jimcrowism from street car service." ${ }^{24}$

"Escape" of a different, more luxurious sort was pitched by the auto industry. A 1915 Model $\mathrm{T}$ ad promised, "Freedom for the woman who owns a Ford: To own a Ford is to be free to venture into new and untried places. It is to answer every challenge of Nature's charms, safely, surely, and without fatigue." ${ }^{25}$ The car

${ }^{21}$ Peter J. Ling, America AND the AUtomobile: Technology, Reform AND Social Change 87 (1990). For an excellent discussion of how racial and class animosities shaped the politics of public transportation including the placement of stations in relation to particular neighborhoods, see id. at 81-92.

${ }^{22}$ Id. at 89 (citation omitted).

${ }^{23}$ The Montgomery, Alabama bus boycott, for example, was triggered in great part by the frustrations of black women passengers: "And I got mad, after this [insult] was over, and I realized that I was a human being, and just as intelligent and far more trained than that bus driver was." DAVIDJ. GARROW, BEARING THE CROSS 14 (1986) (quoting Mrs. Jo Ann Robinson and discussing the efforts of the Montgomery Women's Political Council in the late 1940s and early 1950s to prevent the mistreatment of black riders by city bus drivers); see also Joseph W. Singer, No Right to Exclude: Public and Private Accommodations and Private Property, 90 NW. U. L. REV. (forthcoming 1996).

${ }^{24}$ Blaine A. Brownell, A Symbol of Modemity: Attitudes Toward the Automobile in Southern Cities in the 1920s, 24 AM. Q. 20, 34-35 (1972) (citation omitted).

${ }^{25}$ FORD \& FoRD, supra note 17, at 18. There were exceptions. Robert Lienert describes the effect of the automobile on his mother, who married in 1906: 
secured freedom with safety, adventure with control. Women drivers could move about in public space but were still insulated from direct contact with those outside the car.

As for new and untried places, women, if only wealthy women at first, were thrilled with the possibilities opened up by motor travel. Socialite Christine McGaffey Frederick explained in 1912 that, "[1]earning to handle the car has wrought my emancipation, my freedom. I am no longer dependent on ticksome trains, slowbuggies, the 'old mare,' or the almanac." 26 Edith Wharton, who arrived in England in what Henry James described as a "motor-car of moderate speed and capacious dimensions," 27 similarly enthused that "[t]he motor-car has restored the romance of travel. [It has freed] us from all the compulsions and contacts of the railway, the bondage to fixed hours and the beaten track .... [And] above all these recovered pleasures must be ranked the delight of taking a town unawares. ${ }^{28}$ As more women experienced the liberating pleasure of road trips, a genre of women's travel literature emerged.

When people try to escape from life by setting sail on a ship, they find themselves shut in at close quarters with a lot of other people doing the same thing. When they travel by train, they are still more circumscribed .... But when they drive in a car, their freedom is as nearly perfect as possible. ${ }^{29}$

My parents were married about fifteen years before they bought their first automobile. For my mother, the car did not lead to freedom or open the way to a mobile society.

As the family acquired cars and the "modern" age burst upon her, the private "buggy" horse was displaced. And my mother never learned to drive a car. I never asked why. But I recall that riding in a car made her nervous; and it would have been in character for my father to feel that only men drove cars.

My mother thus had to depend on someone else to take her when she wanted to go anywhere. And since my father often didn't wish to go places, my mother spent a lot more time at home in her mature years.

The automobile, rather than freeing her, confined her more than ever.

Robert M. Lienert, Moving Backward, in THE AUTOMOBILE AND AMERICAN CULTURE 159, 159 (David L. Lewis \& Laurence Goldstein eds., 1980).

${ }^{26}$ Frederick, supra note 1 , at 13.

${ }^{27}$ SCHARFF, supra note 20 , at 23.

${ }^{28} I d$. at 24.

${ }^{29}$ ZEPHINE HUMPHREY, GREEN MOUNTAINS TO SIERRAS 17 (1936). For a collection of short stories that includes several excerpts from women's travel writings, see INDISCREET JOURNEYS: STORIES OF WOMEN ON THE ROAD (Lisa St. Aubin de Terán ed., 1990). 
The social acceptance of women driving accelerated during the First World War when women, including Gertrude Stein, drove ambulances abroad and trolleys at home, replacing the boys who went off to war or aiding those who stayed behind. Wealthy young ladies, like Southern debutante Zelda Sayre Fitzgerald, took soldiers with an afternoon's pass out for a drive, furnishing them, in the words of the Women's Committee of the Council of National Defense, with "healthful amusements and wholesome company." Cars were also used for more egalitarian forms of civic participation. Suffragists publicized their campaign through auto tours and "open-air revivals." As one activist proclaimed, "we must seek on the highways the unconverted!'m32 Thus in its early years, the automobile promised freedom, and relative to women's previous spatial immobility, the automobile delivered.

Automobility made a difference for women isolated by location as well as by social convention. Rural women could now visit friends, receive visitors (including federal farm agent-educators), take their children to the doctor, shop in town instead of from catalogues, attend meetings, and generally "relieve the monotony of the household routine." 33

${ }^{30}$ SCHARFF, supra note 20, at 103.

31 The history of the suffrage campaign in Kansas reveals how the car invigorated the movement by providing crucial mobility in a state where train lines ran only east and west. See Wilda M. Smith, A Half Century of Struggle: Gaining Woman Suffrage in Kansas, in 19 HISTORY OF WOMEN IN THE UNITED STATES: HISTORICAL ARTICLES ON WOMEN's LIVES AND ACTIVITIES (pt. 1) 95, 111, 114 (Nancy F. Cott ed., 1994). Smith explains that once the automobile was in use "the problem, instead of being one concerning the meeting of a schedule, was one of securing the support of those who owned automobiles. This was sometimes solved by persuading a dealer to lend an automobile for a country tour. Obliging dealers obviously felt that it was good advertising for business since it was impossible to miss the suffrage group as it arrived in a car decorated with signs, bunting, and flags." Id. at 114 .

32 SCHARFF, supra note 20, at 81 (quoting Harriot Stanton Blatch).

${ }^{3 s}$ Id. at 142-44; see also JOHN B. RAE, THE ROAD AND THE CAR IN AMERICAN LifE 162-66 (1971) (attributing improvements in rural education and medical care to advances in transportation); Reynold M. Wik, The Early Automobile and the American Farmer, in THE AUTOMOBILE AND AMERICAN CULTURE, supra note 25, at 37, 41-42 ("A Collier's editorial in $\mathbf{1 9 0 9}$ hailed the auto as the strongest force for family and social solidarity in rural America, stronger than telephones, the phonograph, rural free delivery, or university extension work."). 


\section{B. Driving As Constraint}

Driving as liberation might seem a musty concept, but for fortyseven brave Saudi Arabian women motorists who revived the practice in 1990. According to news reports, the women "gathered in a supermarket parking lot, dismissed their chauffeurs and then drove themselves in an orderly procession through downtown Riyadh." ${ }^{34}$ For their troubles all forty-seven were detained by police, fired from their jobs, and denied travel papers. In addition, several mosques broadcast their names over loudspeakers with the demand that they be beheaded. ${ }^{35}$

In the United States the liberating potential of women's driving has been tempered by a different mechanism than the threat of decapitation. My argument is that the freedom to venture into new and untried places has been controlled not by denying women the right to drive, but instead by increasing the obligation. That is, the wind-in-your-hair, dust-in-your-wake aspect of motoring depends very much on where one is going, and why.

Here women's automotive history links up with suburban and feminist geography. ${ }^{36}$ The idea of bucolic, planned communities of single-family homes emerged in the mid-nineteenth century as a middle-class escape from the unhealthful, crowded city. Suburbanization would preserve the American middle-class family:

In the suburban "home town," it was hoped, women would channel their civic energies into mothers' clubs, and would join together on the basis of their children's needs, not their own individual interests. And suburban fathers, with more secure careers in corporate or other organizations, as well as the built-in restrictiveness of commuters' schedules, would spend free time with their families. ${ }^{37}$

34 William Dowell, Life in the Slow Lane, TIME, Nov. 26, 1990, at 46, 46.

${ }^{35}$ See Saudi Arabia: Update on Women at the Wheel, MS., Nov.-Dec. 1991, at 17, 17.

${ }^{36}$ Feminist geography takes as its point of departure that "space is gendered: that is, the design and use of space-like all other cultural constructs-is determined in part by ideological assumptions about gender roles and relations," and "that . . . spatial relations help to maintain and shape culturally specific notions of gender behavior." Joni Seager, Women Deserve Spatial Consideration, in THE KNOWLEDGE EXPLOSION 213, 217 (Cheris Kramarae \& Dale Spender eds., 1992). For an introduction to feminist geography, see MARY E. MAZEy \& DAVID R. LEE, HER SPACE, HER Place: A GEOGRAPHY OF WOMEN 1-4 (1983).

${ }^{37}$ MARGARET MARSH, SUBURBAN Lives 83 (1990). As Stephen Schnably points out, the single-family suburban home continues to "represent[] a whole set of assumptions and lived experiences." Stephen J. Schnably, Property and Pragmatism: A Critique of Radin's Theory of Property and Personhood, 45 STAN. L. REv. 347, 365 (1993). These 
Nineteenth-century suburbs initially developed along public transportation lines, transforming outlying rural areas into accessible residential developments. ${ }^{38}$ In Los Angeles, for example, early developers rarely built houses more than four blocks away from a streetcar line. In contrast, twentieth-century suburbanites relied increasingly on the private car. "Freed from the necessity of living near the streetcar lines, [many] Angelenos ... abandoned the central area altogether and purchased homes well removed from the influence of the [Los Angeles Railway Company]." ${ }^{39}$

The contours and structures of suburbia quickly reflected the centrality of the car. As Kenneth Jackson describes, "[i]n the streetcar era, curbs had been unbroken and driveways were almost unknown." 40 By the 1920s, however, architectural plans of houses commonly incorporated the garage into the house instead of tucking it behind, as the earliest garages had been. ${ }^{41}$ By the $1960 \mathrm{~s}$, the

include the assumption that fulfillment is to be found in private life, the privileged notion that the home is the proper locale for intimate relationships, the idea that communities should be comprised of people of the same race and economic status, and the idea that "the automobile provides a private solution to public transportation needs." Id. at 365-66.

${ }^{38}$ See SAM B. WARNer, JR., Streetcar Suburbs: The Process of Growth in BOSTON, (1870-1900), at 158 (1962) (noting that an increase in population in rural suburbs was largely due to the new streetcar transportation network). The class-based nature of suburban transformation was captured in a 1933 report:

The motor car, bringing the country nearer in time, has caused an unprecedented development of outlying and suburban residential subdivisions. While this development pertains to families of a wide range of income, special attention has been given in the past decade to the promotion of exclusive residential districts designed for occupancy by the higher income classes.

RAE, supra note 33, at 225 (quoting 1 PRESIDENT'S RESEARCH COMM. ON SOCIAL TRENDS, RECENT SOCIAL TRENDS IN THE UNITED STATES 464-65 (1933)).

${ }^{39}$ Scotr L. BotTles, Los ANGeles AND the AutomobILE: THE MAKING of A MODERN CITY 183-87 (1987).

${ }^{10}$ Kenneth T. Jackson, Crabgrass frontier: The Suburbanization of the UNITED STATES 251 (1985).

${ }^{41}$ The first automobiles were stored in private structures or old carriage houses at the rear of the house, accessible by an alley or mews. Because there were few gasoline filling stations, the carriage house/garage was also used to store a supply of gasoline. "This and the fact that cars often caught fire were good and sufficient reasons to keep the motor vehicles away from the family." Id. at 252.

For an excellent discussion of the garage as an architectural innovation, see Folke T. Kihlstedt, The Automobile and the Transformation of the American House, 1910-1935, in ThE AUTOMOBILE AND AMERICAN CULTURE, supra note 25, at 160, 160-75. See also MARSH, supra note 37, at 173 (noting that in the 1920 s architects and builders learned that the garage could "very agreeably be made a part of most dwellings" (citation omitted)). 
garage or carport often dominated the entire front facade. ${ }^{42}$ The once proud front door was now relocated to the side of the house (the inviting porch having disappeared altogether), and as form followed function families now entered their homes directly through the garage.

And who was driving these agreeably garaged cars? Some men drove or carpooled to work, while others took public transportation. Yet even the men who took the morning train relied upon their wives to drive them to and from the station. ${ }^{43}$ And taking the breadwinner to the station was only one of a housewife's driving tasks. She also drove the children to school, to lessons, to doctors, to friends, and to the supermarket to purchase the family's groceries and supplies. In her study of household technologies, historian Ruth Schwartz Cowan points out that along with the rise of department stores and the decline of a servant class, the automobile brought about a drastic restructuring of labor in middle-class households. ${ }^{44}$ The family car obviated the need for grocers to deliver their wares, or for doctors to make house calls. In consequence, housewives moved from being "the receivers of purchased goods [and services] to being the transporters of them. ${ }^{\text {45 }}$

${ }^{42}$ See Kihlstedt, supra note 41 , at 169 . The term "motorcentric" became an architectural term for garage-centered house plans. See id. at 174.

${ }^{13}$ One still finds special "Kiss and Ride" lanes at the suburban Metro stations outside Washington, D.C.

11 See RUTH S. COWAN, MORE WORK FOR MOTHER: THE IRONIES OF HOUSEHOLD TECHNOLOGY FROM THE OPEN HEARTH TO THE MiCROWAVE 79 (1983).

${ }^{15} \mathrm{Id}$. The production of cars also helped maintain traditional gender roles. In 1914 the Ford Motor Company initiated the Five Dollar Day, a minimum daily wage available only to "married men living with and taking good care of their families," to single men of "proven thrifty habits," and to men younger than 22 years old. Martha May, The Historical Problem of the Family Wage: The Ford Motor Company and the Five Dollar Day, in UNEQUAL SISTERS: A MULTICULTURAL READER IN U.S. WOMEN'S HISTORY 275, 284 (Ellen C. DuBois \& Vicki L. Ruiz eds., 1990) (citation omitted). Eventually women were permitted to participate in the Five Dollar Day, but only single women who were the sole providers for their families or married women whose husbands were disabled. See id. Ford's adoption of a family wage may have been motivated by management's interests in reducing employee turnover and thwarting unionization; nonetheless, "[b]y linking gender roles and subsistence, the family wage ideology successfully reinforced the notion that women should receive low wages, or preferably, remain at home." Id. at 287. Modern unions, including the United Auto Workers, have not done much better; most have traditionally opposed the entry of women into the trades. See Marion Crain, Feminizing Unions: Challenging the Gendered Structure of Wage Labor, 89 MICH. L. REV. 1155, 1165 (1991) (illustrating that "[w]idespread acceptance of the assumptions underlying the family-wage ideology ... generated the gendered stereotypes that crept into the workplace"). See generally Kath Weston, Production As Means, Production As Metaphor: Women's Struggle to Enter the 
A new and shrewdly imposed domestic ideology accompanied the technological advances as "[m]anufacturers, advertisers, and the federal government's agencies and bureaus located the 'American standard of living' in the 1920 s in the ... private home. ${ }^{n 6}$ Good housekeeping and superior child rearing represented both accomplishment and modernity as women tried to keep up with the latest advice from experts in psychology, home economics, marital relations, and consumption. ${ }^{47}$

With a small blip for work force participation during the Second World War, in the 1950s middle-class women aspired with new intensity to the kind of mothering that required a driver's license. And while women were not dragged kicking and screaming into the suburbs, ${ }^{48}$ a mighty combination of cultural forces shaped the preference for suburban domesticity:

Gaining ground and credibility from reference to science, and acting as agents of profit-making enterprise, popular media and advertising took the upper hand in prescribing models for fulfillment of womanhood. Not duty imposed by church or state but personal "adjustment" and "fulfillment," demanded from within, called women to the performance. What was unprecedented here was ... the way in which women's household status and heterosexual service were now defended-even aggressively marketed-in terms of women's choice, freedom, and rationality. ${ }^{49}$

Trades, in UnCERTAIN TeRms: Negotiating Gender In AMERICAN Culture 137 (Faye Ginsburg \& Anna L. Tsing eds., 1990) (discussing “occupational sex segregation" and tracing the ways in which women attempt to enter skilled blue-collar jobs and the ways men try to keep them out).

${ }^{46}$ NANCY F. CotT, The Grounding of MOdeRn Feminism 163 (1987). For an excellent synthesis of the physical structure of the suburban home and its cultural meanings and uses, see CLIFFORD E. CLARK, JR., THE AMERICAN FAMILY HOME, 18001960 , at $193-216$ (1986).

${ }^{47}$ See generally BARBARA EHRENREICH \& DEIRDRE ENGLISH, FOR HER OWN GOOD: 150 YEARS OF THE EXPERTS' ADVICE TO WOMEN 3 (1978) (documenting the rise, reign, and fall of "experts"-"physicians, psychologists, domestic scientists, [and] child-raising experts"-on women's health issues).

${ }^{48}$ This is not to say that if women had been in charge, the suburban scene might not have looked a lot different. See generally DOLORES HAYDEN, THE GRAND DOMESTIC REVOLUTION: A HISTORY OF FEMINIST DESIGNS FOR AMERICAN HOMES, NEIGHBORHOODS, AND CrTIES (1981) [hereinafter HAYDEN, DOMESTIC REVOLUTION] (exploring the importance of women's history and feminism on housing design and urban development); DOlores HAYDEN, ReDEsigning THE AMERICAN DREAM: THE FUTURE OF HOUSING, WORK, AND FAMILY LIFE (1984) [hereinafter HAYDEN, REDESIGNING THE AMERICAN DREAM].

${ }^{49}$ CoTT, supra note 46 , at 174 . 
Governmental policies further facilitated the desire for and accessibility of suburban life. Historian Dolores Hayden observed that "[g]overnment-sponsored mortgages and tax deductions for home owners ... provided a great boon to speculative builders, appliance manufacturers, and automobile manufacturers. ${ }^{\text {"50 }}$ Accordingly, by the 1960s, a second car had become less a status symbol than a necessity. ${ }^{51}$

Yet it was not the car itself but rather its use that provided status. Driving provided evidence of good parenting and mileage the measure of maternal contribution to familial welfare. As the cult of the talented child began to emerge, even more driving time was required to transport children to the sources of their enrichment: piano lessons, Little League, and so on. Advertising for family cars emphasized mother-friendly features: power-assisted brakes and steering, automatic transmissions, driver-controlled door locks, built-in child safety seats, and spacious trunks to facilitate the loading of grocery bags.

To the extent that suburban life required both wheels and drivers, it also required a force of unemployed mothers with the time to devote themselves to running a proper household. But how does all this play out in the nineties? There is no longer a staff of 'unemployed' mother-chauffeurs; even mothers with preschool children now tend to work outside the home. ${ }^{52}$ Nonetheless, most working women remain responsible for the same domestic duties as women outside the labor force. ${ }^{53}$ In performing these tasks, working mothers engage in what Arlie Hochschild identified as the "second shift"-paid labor by day and unpaid labor as soon as one

${ }^{50}$ HAYDEN, DOMESTIC REvOlution, supra note 48, at 23.

51 Elaine Tyler May points out that the direct link between postwar consumerism and suburban family values "helped alleviate traditional American uneasiness with consumption: the fear that spending would lead to decadence. Family-centered spending reassured Americans that affluence would strengthen the American way of life." ELAINE T. MAY, HOMEWARD BOUND: AMERICAN FAMILIES IN THE COLD WAR ERA 166 (1988).

52 See Nat'l Comm'N ON Children, Beyond Rhetoric: A New AMERican AGENDA FOR CHILDREN AND FAMILIES 21 (1991).

${ }^{53}$ See David H. Demo \& Alan C. Acock, Family Diversity and the Division of Domestic Labor: How Much Have Things Really Changed? 42 FAM. RELATIONS 323, 326 (1993) (noting that although most women currently work in the wage labor market, "across all family types mothers perform between $68 \%$ and $95 \%$ of the [household] work"); see also Julien Brines, Economic Dependency, Gender, and the Division of Labor at Home, 100 AM. J. Soc. 652 (1994) (noting that the more a husband relies on his wife for economic support, the less housework he will perform). 
gets home. ${ }^{54}$ I want to add an automotive variation to this concept: the "Simultaneous Shift." This is the practice of using time wisely by working in one's car while waiting near the school, next to the practice field, or outside the swim club. ${ }^{55}$

Of course, when compared to city life, many middle class husbands and wives continue to choose the benefits of suburbia: single-family homes, wealthier public schools, and safer streets. ${ }^{56}$ As traditional institutional barriers such as lender redlining and broker steering are dismantled, middle- and upper-class AfricanAmerican families are also moving to predominantly black developments identical to other suburbs in layout, appearance, and convenience..$^{57}$

How then does law fit into all this freely chosen suburban happiness? ${ }^{58}$ The starting place for understanding law's role in fixing

${ }^{54}$ See ARLIE Hochschild, The Second ShIFt: WORKING Parents ANd THE REVOLUTION AT HOME 6 (1989).

55 This is not to say that men do not work in their cars. See Sue Shellenbarger, Work E' Family: Go Mobile and Wreck Your Sense of Balance, WALI ST. J., Feb. 22, 1995, at $\mathrm{Bl}$ (noting that "[s]ix million Americans work from automobiles most of the time ... [a]nd 90\% use the same cars for work and personal needs"). Car phones have turned cars into office annexes so that commuting now extends rather than starts or finishes the work day. But car phone transactions, whether committed by men or women, differ from the Simultaneous Shift in that domestic driving combines paid labor with unpaid labor and professional duties with household responsibilities. Because women disproportionately perform these combined jobs, the Simultaneous Shift is a largely female phenomenon. See, e.g., JULIE A. MATTHAEI, AN ECONOMIC HISTORY OF WOMEN IN AMERICA: WOMEN'S WORK, THE SEXUAL DIVISION OF LABOR, AND THE DEVELOPMENT OF CAPITALISM 305 (Schocken Books 1982) (1982) (discussing how a wife who "has added a paid job to her unpaid housework" must "restructure her life and her homemaking"); Joseph H. Pleck, The Work-Family Role System, in WOMEN AND WORK: PROBLEMS AND PERSPECTIVES 101, 107 (Rachel Kahn-Hut et al. eds., 1982) (describing the asymmetrically permeable boundaries between work and family roles for both men and women" and asserting that "[f]or women, the demands of the family role are permitted to intrude into the work role more than vice versa" (emphasis omitted)).

${ }_{56}$ Jane Jacobs provides a dissenting view, noting that a young man who caused a disturbance in her city neighborhood "turned out to be a wild kid from the suburbs. Sometimes, on Hudson Street, we are tempted to believe the suburbs must be a difficult place to bring up children." JANE JACOBS, THE DEATH AND LIFE OF GREAT AMERICAN CITIES 53 (1961).

${ }^{57}$ See David J. Dent, The New Black Suburbs, N.Y. TIMES, June 14, 1992, § 6 (Magazine), at 18 (discussing how affluent blacks choose to live in affluent black communities); see also BART LANDRY, THE NEW BLACK MIDDLE CLASS 179-81 (1987) (describing the slow rate of black suburbanization in the 1970 s and attributing it to "racial barriers erected by whites to prevent similar choices by blacks" (footnote omitted)).

${ }^{38}$ The common characterization of women's decisions as voluntary works only because it massively discounts the social constraints on what women may choose. 
suburbia's gendered borders might be Justice Douglas's description of the well-protected suburban community: "A quiet place where yards are wide, people few, and motor vehicles restricted[,] ... zones where family values, youth values, and the blessings of quiet seclusion and clean air make the area a sanctuary for people. ${ }^{n 9}$

Historically, women's decisions to marry and have children were "choices" only within a framework of limited social and economic options. For an historic discussion of the economic incentives to marry, see LEE V. CHAMBERS-SCHILLER, LIBERTY, A BETTER HuSBAND: SINGLE WOMEN IN AMERICA: THE GENERATIONS OF 1780-1840, at 36 (1984) (noting that "[c]onsiderations of property, status, or influence were easier to measure than those of affection, respect, and potential happiness"). The importance of marriage for women during the mid-19th century was further revealed by the substantial civil damages recovered by women in breach of promise-to-marry suits. See Michael Grossberg, Governing tHe HeARTH: LAW AND THE FAMILY IN NINETEENTH-CENTURY AMERICA 33-63 (1985). In the 20th century too, marrying and staying married made sense in part because other options for satisfaction and security were unavailable. Restrictions on women's paid work, inadequate divisions of property, and legal traditions linking maternal custody to staying at home reinforced marriage as sensible career choice. Postwar marriage and the move to the suburbs were choices guided not only by the existing ideologies of feminine accomplishment, but also by "national policies supporting suburban home ownership (and consumer credit) for men [which] meant that women's access to housing had to be through their husbands." HAYDEN, DOMESTIC REVOLUTION, supra note 48, at 25. White women in the $1950 \mathrm{~s}$ "chose" the suburbs, yet few other alternatives offered economic security without dependence on a husband. On the inevitability of marriage in the 1950s, see BRETT HARVEY, THE FIFTIES: A WOMEN's ORAL HISTORY 69 (1993) ("The institution of marriage had a power and inevitability in the fifties that it has never had since. You simply didn't ask yourself if you wanted marriage and children; the only relevant questions were when and how many?").

The point here is not to invalidate all spousal consent, but rather to highlight the untrustworthiness of "choice" as a reliable legal designation for the many decisions women make. Feminist scholars continue to point out that despite the restricted contexts in which women make choices or express consent, "choice" as a decision label has had a significant legal consequence. See, e.g., EEOC v. Sears, Roebuck \& Co., 628 F. Supp. 1264, 1305-15 (N.D. Ill. 1986) (finding that the fact that some female employees decided to work part time confirmed women's general lack of interest in full-time high commission sales positions and holding that because of their lack of interest the employer could not be held liable for sex discrimination), aff', 839 F.2d 302 (7th Cir. 1988). But see Joan Williams, Gender Wars: Selfless Women in the Republic of Choice, 66 N.Y.U. L. REv. 1559, 1596-99 (1991) (criticizing the popular use of the word "choice" in public discussions of abortion and maternal employment). Thus the rhetoric of choice was "used to justify outright discrimination by calling up vivid images of selfless mothers choosing family over career." Id. at 1610; see also Vicki Schultz, Telling Stories About Women and Work: Judicial Interpretations of Sex Segregation in the Workplace in Title VII Cases Raising the Lack of Interest Argument, 103 HARV. L. REV. 1749, 1769-99 (1990) (examining how the courts developed a Title VII analysis with two competing explanations-women's "choice" and employer's "coercion"- which have created an unduly narrow definition of sex discrimination and an overly restrictive role for the law).

${ }^{59}$ Village of Belle Terre v. Boraas, 416 U.S. 1, 9 (1974); see also ZONING AND THE American Dream: Promises Still to Keep (Charles M. Haar \& Jerold S. Kayden 
Localities secure these sanctuaries through a variety of familiar zoning and land use restrictions: single-family dwellings with minimum lot sizes and wide setbacks from property lines, prohibitions on commercial or multifamily uses, and narrow definitions of "family" or "household." The plan is quite simple. Zoning and land use restrictions, whether in the form of public ordinances or private covenants, are intended to attract and satisfy wealthy, white, married home owners, and to discourage, if not directly exclude, everyone else: the poor, the unmarried, and the potentially unruly.$^{60}$ Exclusionary zoning, sometimes called "zoning for direct social control, ${ }^{n 61}$ has largely been upheld as a permissible use of the police power. ${ }^{62}$

Critics have focused on a range of problems wrought by restrictive zoning practices: the shortage of affordable housing in pleasant areas, the regressive distribution of the costs of local government, ${ }^{63}$ and the social costs of housing, education, and social life segregated by township boundaries. ${ }^{64}$ What these critiques skip, however, are the deeply gendered implications of exclusionary zoning practices, for restrictive suburban zoning also results in indirect social control. ${ }^{65}$ This occurs not by keeping would-be residents out, but by keeping actual residents in, or at least no farther away than the supermarket.

eds., 1989) (evaluating the 70-year legacy of the Court's first zoning case, Village of Euclid v. Ambler Realty Co., 272 U.S. 365 (1926)).

${ }^{60}$ See Michael N. DANielson, The POLITICS OF EXClusion 1-26 (1976).

${ }^{61}$ J. Gregory Richards, Zoning for Direct Social Control, 1982 DuKE L.J. 761, 765.

${ }^{62}$ See Village of Euclid, 272 U.S. at 390-91 (determining that ordinances establishing residential or commercial areas are neither arbitrary nor unreasonable, and concluding that they are rationally related to the health and safety of the community).

${ }^{63}$ See Paul K. Stockman, Note, Anti-Snob Zoning in Massachusetts: Assessing One Attempt at Opening the Suburbs to Affordable Housing, 78 VA. L. REv. 535, 542-47 (1992) (detailing the consequences of wealth disparity between the cities and suburbs on education, jobs, and citizen morale).

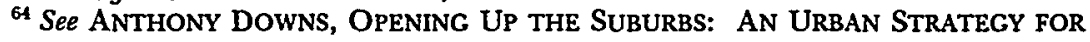
AMERICA 61-67 (1973) (arguing against the exclusion of the poor and minorities from the suburbs). For a considered discussion of the jurisprudence of racial geography, see Richard T. Ford, The Boundaries of Race: Political Geography in Legal Analysis, 107 HARV. L. REV. 1843 (1994).

${ }^{65}$ Sometimes, of course, social control over those zoned in is intentional, the very purpose of establishing the community in the first place. See, e.g., Nomi Stolzenberg, A Tale of Two Villages (Legal Realism Comes to Town) 6, 73 nn.10-11 (1995) (unpublished manuscript, on file with author) (comparing Board of Educ. v. Grumet, 114 S. Ct. 2481 (1994), and United States v. Village of Airmont, 839 F. Supp. 1054 (2d Cir. 1993)). 
How does zoning effectuate this indirect social control? First, the physical layout of suburbia segregates shops and services from housing. This is, of course, the very point of the suburbs. But the system works only so long as there is someone to negotiate the distance between these two spheres. Throughout the 1950s and early 1960s, that special someone was the housewife. Moreover, her options to do something other than facilitate successful suburban life were further limited by the fact that commerce and business were located elsewhere. ${ }^{66}$ Thus we have what Dolores Hayden identified as the "prescriptive architecture" of the suburbs, a geographical region where women keep things clean and excel in on-time deliveries (of children, of goods) and of the cities, an economic region where men work. ${ }^{67}$ Hayden further argues that this arrangement

is inextricably tied to an architecture of home and neighborhood that celebrates a mid-nineteenth century ideal of separate spheres for women and men. This was an artificial environment that the most fanatical Victorian moralists only dreamed about, a utopia of male-female segregation they never expected the twentieth century to build. ${ }^{68}$

${ }^{66}$ Martha Mahoney makes a similar argument with regard to occupational disadvantage and racially segregated housing. See Martha Mahoney, Note, Law and Racial Geography: Public Housing and the Economy in New Orleans, 42 STAN. L. REv. 1251, 1260-62 (1990) (describing the interrelationship between public housing and employment).

${ }^{67}$ HAYDEN, REDESIGNING THE AMERICAN DREAM, supra note 48 , at 40.

${ }^{68} I d$. In addition to distancing women from work sites, utopian land use regulations further restrict women's occupational opportunities by zoning child care out of residential neighborhoods. See William Michelson, Spatial and Temporal Dimensions of Child Care, SIGNS, Spring 1980 (Supp.), at S243, S245 (explaining in peculiarly gender-neutral language that "[s]ome segments of the population, undertaking multiple roles, are more subject to constraining effects from rigid or irrational timetabling and land-use patterns"); see also SANDRA L. HOFFERTH ET AL., NATIONAL

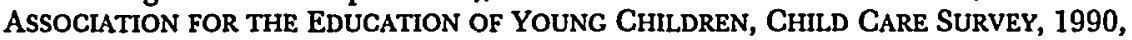
at 223 (Urban Inst. Report No. 91-5, 1991) (noting that location is the most important factor, second only to quality, when parents consider their child-care arrangements). Family day care is the term for child care located in the provider's home. Many parents prefer family day care because it is cheaper than in-home care, cozier than a day-care center, and often keeps the children in their own neighborhood. See CAL. HEALTH \& SAFETY CODE \$ 1597.30(d) (West 1990) (acknowledging that "[m]any parents prefer child day care located in their neighborhoods in family homes"). Providing family day care also solves the dilemma of mothers who want to earn income while raising their own children. See generally HOMEWORK: HISTORICAL AND CONTEMPORARY PERSPECTIVES ON PAID LABOR AT HOME (Eileen Boris \& Cynthia R. Daniels eds., 1989) (describing the many forms of wage labor women perform in their homes, often to satisfy their need for income and child care). Despite these "down- 


\section{Cars and Class}

While the problem of the chauffeuring mother, a captive of suburbia, may ring true for many readers, the concept of driving as subordination also reveals the complications of class. After all, isn't driving a car better than riding the bus? How bad can a life attached to a soccer field be? Shouldn't we regard "suburban subordination" as a complaint of the lucky and move on to women's more pressing problems?

Without question, access to reliable, low-cost transportation-private or public-improves the quality of women's lives and of their families. Carlessness disadvantages women in a number of ways. A mid-1960s study of the planned community of Levittown explained the "poor disposition" reported by many young mothers: "Without a car or compatible neighbors, there is no respite or escape. ${ }^{\text {69 }}$

For many women, downtown shopping and window-shopping opportunities are sufficient to overcome physical isolation, but quick and easy access to the city [of Philadelphia] is now not available, and some even have trouble getting to the Levittown shopping center. ${ }^{70}$

Women who relocated to outlying Chicago suburbs similarly listed isolation and transportation problems as the main disadvantages of the move. ${ }^{71}$

home" advantages of family day care, it is nonetheless a business and thus often prohibited in areas zoned residential. See Lori E. Pegg, Note, Family Day-Care Homes: Local Barriers Demonstrate Needed Change, 25 SANTA ClARA L. REv. 481 (1985) (addressing whether zoning ordinances are the proper vehicle for meeting the demand for adequate family care); see also Patrice Z. Ticknor, Note, Obstacles to Family Day Care Homes in Michigan, 34 WAYNE L. REv. 1445, 1445 (1988) (examining the "legal barriers[,] . . . restrictive covenants and zoning ordinances [that] often exclude [registered family day-care homes] from Michigan communities"). In addition to the business exclusion, restrictive covenants and stringent permit and building code requirements have also been used to keep family day care out. Providers and their advocates argue that caring for a small number of children in one's home is not inconsistent with a residential environment. Five children or so in home-based day care differ little from a large family. A number of states have accepted this logic. For example, California has enacted legislation establishing that " $[t]$ he use of single-family residence as a small family day-care home shall be considered a residential use of property for the purposes of all local ordinances." CAL. HEALTH \& SAFETY CODE \$ 1597.45(a) (West 1990).

${ }^{69}$ Herbert J. GaNS, The LevitTowners: Ways of Life and Polttics in A NEW SUBURBAN COMMUNITY 226 (1967).

${ }^{70} I d$. at 241.

${ }^{71}$ See Helena Z. Lopata, The Chicago Woman: A Study of Patterns of Mobility and 
Elderly women are specially vulnerable. A 1974 empirical study of "the carless" in Buffalo, New York, revealed that the most disadvantaged - "those who never or seldom had a car available for any purpose"-were unemployed women over fifty-nine. ${ }^{72}$ Many older women do not drive, "having lived their adult lives when cars were considered the province of men." ${ }^{73}$ After their husbands die, many widows tend to dispose of the their husband's car. ${ }^{74}$ In certain ethnic communities, women tend not to drive and so remain dependent on husbands or other male relatives to get around.

For poor women with jobs, good transportation makes life easier. Consider the case of classroom aide Danita Woodley, a carless New Yorker who lives beyond the subway:

[Woodley] leaves her house in St. Albans, Queens each morning, towing her toddler son, and rides a bus to Jamaica Center, where she catches the J train to her son's baby sitter in Brooklyn and then to work at Public School 290 in East New York. An hour and a half-and any number of possibilities for delay. ${ }^{75}$

For those seeking jobs, reliable transportation can be crucial. A 1986 study of Michigan's mandatory work requirement program for AFDG recipients, most of whom are women, found that the "lack of adequate transportation continues to be a major disincentive to full

Transportation, SIGNS, Spring 1980 (Supp.), at S161, S163 (explaining that " $[\mathrm{t}]$ he combination of mortgage, transportation costs, and the drop in income after the wife quits working" made buying a second car more difficult, "push[ing] many Chicago area families into a curtailed social life space").

72 ROBERT E. PAasWell \& Wilfred W. ReCKer, Problems of the CARLESS 162 (1978). In the mid-1970s, fewer than five percent of women over 59 in Buffalo had a valid driver's license, likely a result of coming into adulthood at a time when women did not drive as a matter of course and of living in a city where fewer people in general drive. See id.; see also Lienert, supra note 25, at 159 (explaining that although the author's mother rode her own horse for transportation before the advent of the automobile, she never learned to drive a car).

${ }^{73}$ Lopata, supra note 71, at S166; see also Lienert, supra note 25, at 159 (relating a story of a woman in the early 1900 s who never learned to drive a car and how the "automobile, rather than freeing her, confined her more than ever").

${ }^{74}$ See Lopata, supra note 71, at S167. See generally Elizabeth W. Markson \& Beth B. Hess, Older Women in the City, SIGNS, Spring 1980 (Supp.), at S127, S138 (explaining that one problem plaguing older urban women is erratic access to public transportation). "Low income elderly ... are more bothered by the costs of buses or subways than are people of higher incomes. Not all public routes go where one wants to; cabs must be used. Subway stairs are long and steep, and the connecting tunnels can be fear-inducing." Id. (footnote omitted).

${ }^{75}$ Steven Myers, Life Beyond the Subway Is Subject to Its Own Disruptions, N.Y. TIMES, June 14, 1992, at 43. Woodley's daily trek was made all the more difficult in 1992 when the private bus companies that service 225,000 residents of Queens, Brooklyn, and the Bronx went on strike. See id. 
[program] participation. ${ }^{\text {76 }}$ A study of Canadian women similarly reports that owning and driving a car

influences a woman's ability to ... seek employment beyond the immediate vicinity of her home or neighbourhood .... While metropolitan areas may be well serviced by public transportation, owning and driving a car is an important element in mobility for many women, especially single parents, in suburban areas, in smaller towns, and in rural areas. ${ }^{77}$

The importance of a car for poor women is also reflected in Chapter 5 of the Bankruptcy Code, which protects the car as one of the debtor's most valuable assets. ${ }^{78}$

Access to a car is also crucial to women in terms of facilitating household labor. In the Buffalo carlessness study, investigators identified several types of "nonwork" car activities, including shopping, banking, visiting friends and doctors, taking children to school, and going to church. ${ }^{79}$ Those without cars ranked "grocery shopping, medical trips, going to the bank, and clothes shopping" as the most essential. ${ }^{80}$

"Carlessness" also locks women into local stores and high local prices. Sociologist Marjorie DeVault explains the distributional ironies of inadequate transportation for poor women: "[S]ome of the prescribed techniques of 'smart' shopping are not always appropriate or even possible. The poorest women ... were well aware that the stores in their neighborhoods charged more for many food items than stores in other areas. "81 In order to buy bargains, women without adequate transportation must rely on friends or

${ }^{76}$ Patricia L. Sorenson, Women, Work and Welfare: A Summary of Work Incentives and Work Requirements for AFDC Recipients in Michigan, 20 CLEARINGHOUSE REV. 110, 118 (1986) (noting that for young parents, inadequate transportation may affect "transportation both to the workplace and to the child care center or babysitter").

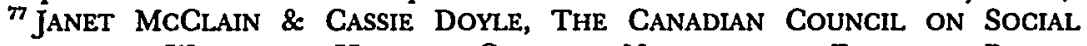
DEVELOPMENT, WOMEN AND HOUSING: CHANGING NEEDS AND THE FAILURE OF POLICY 56 (1984) (reporting that $49 \%$ of all women heads of households own automobiles, compared with $88 \%$ of men).

${ }^{78}$ See Bankruptcy Act of 1978, 11 U.S.C. $\$ 522(d)(2)$ (1994) (exempting from the property of the bankruptcy estate the debtor's interest in a motor vehicle, not to exceed \$2400). See generally Teresa A. Sullivan et Al., As We Forgive Our DEBTORS: BANKRUPTCY AND CONSUMER CREDIT IN AMERICA 147-65 (1989) (stating that there has been pressure in recent history to provide women with economic equity "apart from the institution of marriage").

${ }^{79}$ See PAASWELL \& RECKER, supra note 72, at 162.

${ }^{80} \mathrm{Id}$. at 163.

${ }^{81}$ Marjorie L. DeVault, Feeding the Family: The Social Organization of CARING AS GENDERED WORK 178 (1991). 
relatives or pay extra money for a delivery service or a cab. ${ }^{82}$ The unavailability of transportation similarly affects the quality of a family's medical care, as getting to distant clinics on public transportation with children in tow is tiring, time-consuming work, especially in colder climates. ${ }^{83}$

These various predicaments reveal the extent to which a car can improve the material circumstances of poor women's lives. Control over one's transportation facilitates the performance of both family labor and wage work. The disadvantages of carlessness-or of inadequate public transportation-are therefore far greater for the poor than for wealthier women who, even if carless, can afford to take cabs, order deliveries, and hire surrogates to do their shopping or fetch their children. ${ }^{84}$

At the same time, however, I don't want to lose sight of how the car obscures the work performed by all women. Ruth Schwartz Cowan introduced this phenomenon with regard to household technology in general-the refrigerator, the automatic washing machine, and so on. Such devices appear to lessen the amount of work that women do, but as Cowan observes, "[m]odern laborsaving devices eliminated drudgery, not labor. ${ }^{~} 85$ Linda Gordon extends Cowan's point to the sex-based structure of public assis-

${ }^{82}$ See id.

2see, e.g., Urban Strategies Council, A Change for Every Child: OAKLAND's INFANTS, CHILDREN AND YOUTH AT RISK FOR PERSISTENT POVERTY 20 (1988) (noting that many Oakland "neighborhoods are now devoid of the diversity of professionals, the array of quality health and public maintenance services, as well as the schools and stores they once had"); id. at 29 (noting that Oakland's infant mortality rate "soars" above the national average); Lopata, supra note 71, at $\$ 163$ (reporting that full-time homemakers and mothers in Chicago feel "tied down" for years due to the problems of traveling with small children on public transportation, especially in winter).

\&4 For a discussion of the physical dangers associated with public transportation, see infra notes 109-11, 115 and accompanying text.

${ }^{85}$ CowaN, supra note 44, at 100-01. Certain kinds of women's work, such as planning meals, are literally invisible in that the job takes place unobserved in the planner's head, See DEVAuLT, supra note 81, at 55-56. Other kinds of work are visible but obscured. For example, early auto advertising for women pitched women's use of the car as recreational. Shopping was not so much work as a pleasant outing. To some extent this was so. Shopping did get women out, and even running errands may have been preferable to staying home. But somewhere in all this fun, the fact of women's domestic labor became obscured. Virginia Scharff argued that the obscurance was deliberate; even the language used to describe automotive improvements masked the fact of women's work. Features that saved the housewife time and energy-for example, larger trunks for groceries and storage compartments-were "trivialized as optional and somehow frivolous 'convenience,' rather than celebrated as 'efficiency," the word used to describe improvements related to serious work and productivity. SCHARF, supra note 20, at 149. 
tance. She argues that the entire system relies on the assumption that "women will be available to make it possible for the aid to be delivered: to drive, to care, to be at home for visits, to come to welfare offices. ${ }^{n 66}$ Gordon's observation, while properly focused on the poor, underscores a commonality among women in general: the invisibility of their labor. Women's labor is essential (although unpaid and undervalued) in both the private market and in what Gordon identifies as the welfare economy. ${ }^{87}$ In both systems the car camouflages (even as it eases) the real work that driving represents.

\section{CARS ANd SEX: ThE "Boudoir on WheEls"}

Using one's car as a place for work, a sanctuary for thought, or a hall for music takes us from the car as a means of transportation to consideration of the car as a place. The concept of the automobile as a place was central to early marketing campaigns in the mid1920s. Advertising of the period touted the closed car as "a delightful living room on wheels," a "drawing room on wheels," even a "boudoir on wheels," 88 a characterization to which we shall return. These descriptions were directed at women consumers, already recognized as influencing, even if not financially controlling, the purchase of the family automobile. ${ }^{89}$ Industry experts explained that a " $[\mathrm{m}]$ other sees the car, like the home, as a means for holding the family together, for raising the standard of living, for providing recreation and social advantages for the children."m90 The car also served as a vacation home as families enthusiastically took up the new pastime of "autocamping. ${ }^{\text {"1 }}$ "[P]ioneering in a Chevrolet coach," explained travel writer Zephine Humphrey in 1936, meant that " $[t]$ he burden of home life was discarded, but the essence of it we had with us in the four walls of our car. ${ }^{92}$

${ }^{86}$ Linda Gordon, The New Feminist Scholarship on the Welfare State, in WOMEN, THE STATE, AND Welfare 9, 12-13 (Linda Gordon ed., 1990).

${ }^{87}$ See id. at 13.

${ }^{88}$ Id. at 125.

${ }^{89} \mathrm{Cf}$. infra note 193 and accompanying text (noting that women now buy one-half of new cars and that advertisers have ads that target women).

${ }^{90}$ SCHARFF, supra note 20, at 125 (quoting John C. Long, Ask Mother-She Knows, MOTOR, Sept. 1923, at 92, 92).

${ }^{91}$ See WARren J. BELASCO, AMERICANS ON THE RoAD: From AUTOCAMP to MOTEL, 1910-1945, at 7 (1979) (noting that "auto-camping began as a vacation alternative for the relatively comfortable middle classes ${ }^{n}$ ).

${ }^{92}$ HUMPHREY, supra note 29 , at 17-18. 
Today the car still functions as a residence of sorts, a movable space in which the driver feels "at home," although for homeless families who actually live in their cars the car as "home" has taken on a less salubrious meaning. ${ }^{93}$ Yet for those with a choice, an enthusiastic preference to engage in a range of social activities from the comfort and privacy of one's car remains:

People do not go to drive-in movies because it is more convenient; they go to drive-ins because they like sitting in their cars, where they can watch the film from their own territory, not from an impersonal seat in someone else's space. Because it is their little living room on wheels they can do what they like inside it; talk, smoke, eat, kick off their shoes, have sex or go to sleep. ${ }^{94}$

The early pitch to women of the car as a mobile home emphasized such feminine concerns as the quality of the upholstery and the design and placement of vanity cases. Although we may no longer think about cars as little homes in quite this way-cars as lounges or powder rooms-the concept still has some relevance if only because there is often no other time or place for women to do a

${ }^{93}$ Compare Hershey v. City of Clearwater, 834 F.2d 937 (11th Cir. 1987) (upholding an ordinance which prohibited "lodging" in one's car because it was neither overbroad nor vague) with City of Pompano Beach v. Capalbo, 455 So. 2d 468 (Fla. Dist. Ct. App. 1984) (declaring unconstitutional an antihomeless ordinance which prohibited sleeping in one's car, because it vests too much enforcement discretion in the police), cert. denied, 474 U.S. 824 (1985); see also Judith Cummings, New Califormia Homeless Move from Park to Park, N.Y. TIMES, Aug. 7, 1982, at 6 (noting that "[o]nly a few miles from some of the most expensive communities in affluent Orange County," homeless families live "in tents, vans and cars in public parks"); Timothy Egan, School for Homeless Children: A Rare Experience, N.Y. TIMES, Nov. 17, 1988, at A20 (noting that schools specially designed for homeless children cannot reach children who live in cars because, unlike children who live in homeless shelters, it is impractical to supply them with bus service); Sally Friedman, Helping Homeless Pregnant Teen-Agers, N.Y. TIMES, July 14, 1991, § 12 (New Jersey Weekly), at 8 (noting that homeless, pregnant teenagers often live in cars and vacant buildings in order to survive); Eric Schmitt, Suburbs Wrestle with Steep Rise in the Homeless, N.Y. TIMES, Dec. 26,1988 , at 1, 36 (noting that the suburban homeless "are less visible than the urban homeless, often living in . . . abandoned cars or shopping center parking lots"); Karen L. Ziner, More Families Are Among Homeless, N.Y. TMES, Dec. 29, 1985, § 23 (Connecticut Weekly), at 12 (quoting a recent report of the National Coalition for the Homeless finding that "there may be as many as 10,000 homeless in [Connecticut] but only 950 beds available in emergency shelters").

94 Peter Marsh \& Peter Collett, Driving Passion: The Psychology of the CAR 7 (1986). One might add other activities to the list: attending church, putting on make-up, and participating in modern civic life through talk-radio-the current and mobile marketplace of ideas. Indeed, part of the outrage over carjackings may be the particular sense of violation one feels when a stranger intrudes into this protected domestic zone of privacy. 
particular thing. As places, cars become subject to the logic of places and the familiar paradoxes of the public-private distinction. The private realm of domesticity to which women were long assigned provided them with a zone of limited authority. At the same time, the privacy of the home retained a darker side: it left women unprotected from violence perpetrated by other members of the household. The home has been a place where battery and rape have been permissible, where neither police nor courts would interfere.

In much the same way, the car is also a place of freedom and a zone of danger. For many women who regularly commute or deliver others, the car is a refuge, a place of personal privacy to think, read, or scribble notes while parked. But for many, reading is not the activity that first comes to mind when thinking about women in cars. Much more energy and attention has been devoted to the possibility of sex in cars. This is where the car emerges as a place of danger.

\section{A. The Perils of Privacy}

The potential of cars for providing both the opportunity and location for sexual encounters caught on quickly. Couples, the parents of couples, moral crusaders, sociologists, and even car manufacturers all took note. "Henry Ford, according to widespread rumor, sought to discourage sex through car design. The auto king allegedly limited his Model T's seat length to thirty-eight inches so as to inhibit lovemaking in Tin Lizzies."95

The social history of courtship reveals the influence of cars on the customs of modern dating. ${ }^{96}$ Cars shifted the initiative for social contact from girls, who had formerly invited suitors to call, to boys, who now invited girls out. Dating also changed the distribution of power over courtship practices by shifting control away from parents to the daters themselves. ${ }^{97}$ As Helen and Robert Lynd

${ }^{95}$ David Lewis, Sex and the Automobile: From Rumble Seats to Rockin' Vans, in THE AUTOMOBILE AND AMERICAN CULTURE, supra note 25, at 123, 127.

${ }^{96}$ See BeTH L. BAILEY, From FroNt PORCH to BACK SEAT: COURTSHIP IN TWENTIETH-CENTURY AMERICA 19 (1988) (explaining how the invention of the automobile contributed to the rise of dating by giving young people both privacy and mobility).

${ }^{97}$ Dating also moved the location of courtship, and thereby changed the formal practices that had surrounded this form of intimacy. As architect Folke Kihlstedt explains:

The parlor and the front porch supported a formal style of life. . . This 
observed in their 1929 study:

The extensive use of this new tool by the young has enormously extended their mobility and the range of alternatives before them; joining a crowd motoring over to dance in a town twenty miles away may be a matter of a moment's decision, with no one's permission asked..$^{98}$

Of course, with the exception of darkened cinemas, most places-the soda shop, the ballroom, the boardwalk-remained subject to some public supervision, if only by peers. Only in the transit between these places and the home was real privacy possible. ${ }^{99}$ This intimate realm of vehicular privacy is sometimes good. Couples may want to share unscrutinized moments; the car has been reported as the most common site for marriage proposals. But the realm of solitude is also understood as dangerous. As we

style was built around an accepted social hierarchy in which a progression of architectural spaces, from front porch (or veranda) to hall to parlor to library (or sitting room) and to dining room, were related to increasing degrees of intimacy.

Kihlstedt, supra note 41 , at 162 . Cars disrupted this spatial hierarchy by relocating courtship outside private homes and away from parental scrutiny.

${ }^{98}$ HELEN LYND \& ROBERT LYND, MIDDLETOWN 137 (1929).

The degree to which parents permitted daughters an independent social life in the public sphere varied among different immigrant groups. Chaperonage remained an important institution among East Side Jews, but parents considered it appropriate for their daughter to go for walks and to dances with men, as long as the parents knew about the excursion beforehand and had met the young man. ... In contrast, Italian girls were most likely to engage in home-centered amusements ....

... Chaperones [sic] usually accompanied young women who went out in the evening, and the modern concept of dating was alien to most Italian parents. The requirements of courtship assumed that a woman went out only with the man she would ultimately marry. Rather than attending dances and theaters, the couple would visit at her home several times a week until the courting year had ended.

KATHY PEISS, CHEAP AMUSEMENTS: WORKING WOMEN AND LEISURE IN TURN-OF-THECENTURY NEW YORK 68-69 (1986).

${ }^{99}$ Other spots for sex included early motels or "autocamps" or "autocourts." As Warren Belasco observed in his history of autocamping, "the couple trade was quite profitable, since single cabins could be rented several times a day." BELASCO, supra note 91, at 149. In order to establish respectable reputations, "camps began to require registration-name, address, license plate-and they refused rooms to local people and travelers without bags." Id. This did not keep FBI Director J. Edgar Hoover from charging that autocamps in the 1930 s were "dens of vice and corruption,' haunted by nomadic prostitutes, hardened criminals, white slavers, and promiscuous college students." Id. at 168 (footnote omitted). 
shall see, because cars provide a male-controlled privacy, they are also common sites for sexual assaults. ${ }^{100}$

For parents of daughters, the car as a location for sex provoked two concerns. The first was that one's daughter might be overpowered by her date. The second, perhaps more upsetting concern, was that the daughter might consent. ${ }^{101}$ As the Lynds explained, the car was responsible for the "increasing relaxation of some of the traditional prohibitions upon the approaches of boys and girls to each other's persons." 102 Thus riding in cars with boys has been a common factor in parental determinations that their daughters are "incorrigible" or "beyond control" and therefore in need of court supervision. ${ }^{103}$ As early as the mid-1920s, the Lynds found that:

The threat which the automobile presents to some anxious parents is suggested by the fact that of thirty girls brought before the juvenile court in the twelve months preceding September 1, 1924, charged with "sex crimes," for whom the place where the offense occurred was given in the records, nineteen were listed as having committed the offense in an automobile. ${ }^{104}$

${ }^{100}$ See infra part II.B.

101 The distinction between being overpowered and giving consent is sometimes thin. Consider the quality of consent in Michael M. v. Sonoma County Super. Ct., 450 U.S. 464 (1980), where "[a]fter being struck in the face for rebuffing petitioner's initial advances, Sharon submitted to sexual intercourse with petitioner." Id. at 467. According to Justice Blackmun, Sharon appeared "not to have been an unwilling participant in at least the initial stages of the intimacies that took place the night of June 3, 1978." Id. at 483 (Blackmun, J., concurring); see also Frances Olsen, Statutory Rape: A Feminist Critique of Rights Analysis, 63 TEx. L. REv. 387, 416-17 (1984) (disagreeing with the characterization of the sexual encounter in Michael $M$. as consensual and describing the Michael $M$. transcript as "a forceful indictment of our present gender system").

${ }^{102}$ LYND \& LYND, supra note 98, at 137.

${ }^{103}$ Occasionally husbands have faced the prospect of their wives consenting to sex with someone else in their automobile. In Sargent v. Sargent, 114 A. 428 (N.J. Super. Ct. Ch. Div. 1920), aff'd, 114 A. 439 (N.J. 1921), Mr. Sargent sued his wife for divorce on the fault-based grounds that she was having an affair with the family chauffeur, Mr. Simmons. See id. (In wealthy households, the garage housed not just the automobile but the chauffeur as well.) The petition was denied on the common law grounds of the husband's participation or connivance:

[S]uspect[ing] [his wife] of an inclination for illicit relations with Simmons ... he should have taken the step which lay within his power to keep Simmons away from his home, namely, discharge him and warn him never to come to his house again. Instead, he retained Simmons in his employ. Thus he gave Simmons the chance to be with his wife frequently in the automobile and also an excuse for and opportunity to be at his house at all times during the day when [he] was absent at his business.

Id. at 438.

${ }^{104}$ LYND \& LYND, supra note 98, at 258. 
The Lynds concluded that "[h]ere again the automobile appears to some as an 'enemy' of the home and society." 105 Foreshadowing the Beach Boys' advice about "Fun Fun Fun" by some forty years, an Atlanta judge in 1921 declared that "[i]t is not too much to ask the parents to throw in the clutch and put on the brakes or our entire civilization will take one last joy ride to destruction." 106 Girls who rode found themselves not only in juvenile court but in homes for unwed mothers as well. The Salvation Army in Nashville, Tennessee, estimated in 1926 that the majority of unwed mothers in its maternity homes were the victims of "the predatory drivers of automobiles.'"107

\section{B. Risking Rape}

With regard to nonconsensual sex, cars increase the danger. Women get waylaid, transported, assaulted, and raped in cars, ${ }^{108}$

\section{${ }^{105} I d$.}

${ }^{106}$ Brownell, supra note 24, at 38 (citation omitted). Beverly Donofrio describes a typical mother's response to her protesting 14-year-old daughter in 1963: "You'll ruin your reputation. You're too young. Boys think they can take advantage. Remember what I told you. If a boy gets fresh, just cross your legs." BEVERLY DONOFRIO, RIDING IN CARS WITH BOYS 17 (1990). For girls who choose not to take this advice, parents continue to turn to the status offense jurisdiction of the juvenile court for support. Coming home late from a date, seeing a boy against parental wishes, and staying out all night provide the most common grounds for status offense petitions filed against girls by their parents. See R. Hale Andrews, Jr. \& Andrew H. Cohn, Note, Ungovernability: The Unjustifiable Jurisdiction, 83 YALE L.J. 1383, 1389 n.41 (1974) ("By sex, girls receive a notably higher proportion of the following allegations than their $\mathbf{5 7}$ percent representation in the sample of petitions as a whole: ... bad companions, 73 percent; ... undesirable boyfriend, 100 percent; ... promiscuity, 100 percent; . . . spending the night with a boy, 100 percent; general sex innuendo, 100 percent."); Meda Chesney-Lind, Judicial Paternalism and the Female Status Offender: Training Women to Know Their Place, 23 CRIME \& DELINQ. 121 (1977) (stating that traditional family norms require greater obedience from girls and that families tend to be less tolerant when they violate status offenses); Alan Sussman, SexBased Discrimination and PINS Jurisdiction, in BEYOND CONTROL: STATUS OFFENDERS IN THE JUVENILE COURT 179 (Lee E. Teitelbaum \& Aidan R. Gough eds., 1977) (focusing on the unequal treatment of male and female children in the extension of juvenile court jurisdiction to persons in need of supervision). See generally Marlene D. Beckman, Note, The White Slave Traffic Act: The Historical Impact of a Criminal Law Policy on Women, 72 GEO. L.J. 1111, 1111 (1984) (tracing "the transformation of the Mann Act from its original formulation as a weapon against commercial vice to its eventual use as a federal morals law").

${ }^{107}$ Brownell, supra note 24, at 39 (citation omitted).

${ }^{108}$ See Woman Is Raped by 'Rescuer', THE TIMES (London), Aug. 20, 1990, at 5 (describing a case in which a woman who escaped from two rapists was also raped by her "rescuer" after offering to drive her home). 
buses, ${ }^{109}$ and taxis, ${ }^{110}$ at bus stops, ${ }^{111}$ in parking lots, ${ }^{112}$ and on the shoulders of highways. ${ }^{113}$ The logic of these attacks is not hard to figure out. Women in cars are alone in confined spaces from which exit is difficult, especially when the vehicle has been driven to an isolated or unfamiliar spot. ${ }^{114}$ Bus stops and train stations are similarly dangerous places, ${ }^{115}$ as women often wait or are dropped off alone, sometimes at night after work.

${ }^{109}$ See CTA Driver Arrested in Attack on Bus, CHI. TRIB., June 23, 1992, at C3; Phil Sneiderman, RTD Driver Held in Sexual Assaults; Crime: He Is Accused of Raping One Passenger Aboard His Bus and Attempting to Attack Another, L.A. TIMES, Nov. 12, 1991, at Bl; Terry Wilson, School Bus Driver Convicted of Rape, CHI. TRIB., Apr. 22, 1992, at C3.

${ }^{110}$ See Yigal Kotzer, Taxi Driver Tried to Rape Woman, 70, JERUSALEM POST, Nov. 26, 1991, at 2; Seven Years for Cab Driver Who Raped Passengers, Press Assoc. Newsfile, Apr. 3, 1992, available in LEXIS, News Library, Wires File; David Silverman, 'Taxi' Ride Turns into Kidnapping, Rape Ordeal, CHI. TRIB., Nov. 25, 1991, at C3; 16 Years for Rapist Who Posed As Taxi Driver, Press Assoc. Newsfile, Jan. 19, 1990, available in LEXIS, News Library, Wires File; Letta Tayler, Cabbie Held in Sex Attack on Girl, 11; Accuser, Told to Wait, Runs Away, NEwSDAY (N.Y.), Aug. 6, 1991, at 25, available in LEXIS, News Library, Arcnws File.

"1" See Conrad deFiebre, Girl, Woman Report Rape, Abduction from Bus Stops, STAR Trib. (Minnesota), Nov. 6, 1991, at 1A; Paul Duggan, Md. Court Adds 40 Years to Murderer's Life Term, WASH. POST, Aug. 25, 1989, at B1 (reporting that the murderer lured one of his victims from a bus stop and raped her); April Lynch, Muni Driver Who Shut Door in Rape Case Still Sought, S.F. ChRoN., Jan. 13, 1993, at A11; Sandra McIntosh, Man Indicted in Murder, 2 Rapes Near Bus Stop, ATLANTA J. \& ConST., Jan. 30, 1991, at B1; Kathy Scruggs, Rape Suspect Is Charged in Assault on 2nd Woman, ATLANTA J. \& CONST., Mar. 8, 1993, at B6 (reporting that a victim was stalked every day for two months prior to being raped while walking home from her bus stop); see also Werndli v. Greyhound Lines, 412 So. 2d 384, 386 (Fla. Dist. Ct. App. 1982) (finding that a common carrier may have a duty to warn female passengers about dangerous conditions in and around the station at their destination).

${ }_{112}$ See Gomez v. Ticor, 145 Cal. App. 3d 622, 628 (Ct. App. 1983) (noting "the unique nature of a parking complex, which invites acts of theft and vandalism[,] . . . [and which may lead to r] obbery, rape, and violent consequences to anyone who interrupts these crimes"); People v. Blake, 474 N.E.2d 892, 894 (Ill. Ct. App. 1985) (convicting defendant of rape, which involved forcing his victim into his van in the parking lot of a restaurant).

${ }^{113}$ See, e.g., Chaney v. State, 757 S.W.2d 226 (Mo. Ct. App. 1988). In this case the defendant pulled up beside the victim on Interstate 270 , and "gestured in such a manner that she believed she had car or tire trouble." Id. at 227. She then drove her car onto the shoulder where the defendant looked under the hood of her car. He then got into her car and raped and sodomized her. See id.; see also Scruggs, supra note 111, at B6 (reporting that a man raped and kidnapped a woman after a PTA meeting when her car ran out of gas).

${ }^{114}$ See Jane E. Brody, Personal Heallh, N.Y. TIMEs, Apr. 29, 1992, at B7 (reporting that when a woman is forced into a car by a male aggressor "in a very high percentage of cases ... [ [she] will not survive the attack").

${ }^{115}$ See, e.g., Suspects Sought in Rape at CalTrain Station, S.F. CHron., Apr. 30, 1992, at $\mathrm{A} 18$ (reporting that a woman was raped while waiting for a train). 
Women are at risk even when they are driving. In State $v$. $R u s k,{ }^{116}$ the victim gave Rusk a ride to his apartment after meeting him in a bar. ${ }^{117}$ On reaching his apartment, she stayed in her car with the motor running, refusing his repeated invitations to come to his room. Rusk then turned off the ignition and took her keys. The victim testified that

At that point, because I was scared, because he had my car keys. I didn't know what to do. I was someplace I didn't even know where I was. It was in the city. I didn't know whether to run. I really didn't think at that point, what to do. ${ }^{118}$

Rusk argued that the victim demonstrated her consent to sexual intercourse by going up to his room. ${ }^{119}$ The court upheld his rape conviction on the grounds that "the jury could have reasonably concluded that the taking of her car keys was intended by Rusk to immobilize her alone, late at night, in a neighborhood with which she was not familiar. ${ }^{120}$

Taxi cabs intensify women's 'vehicular vulnerability. ${ }^{121}$ The passenger is less likely to know where she is or that she has strayed from the proper route. There is also a heightened expectation of security in a cab; after all, it is a costly way to travel that implicitly involves confidence in the driver. In a London rape case the victim looked specially for a black London cab with its light on, which the prosecutor cited as a well known "symbol of trust."

${ }^{116} 424$ A.2d 720 (Md. 1981).

117 The victim testified that as she and the defendant left the bar, she cautioned him that "I'm just giving [you] a ride home, you know, as a friend, not anything to be, you know, thought of other than a ride." Id. at 721.

${ }_{118} I d$.

${ }^{119}$ See id. at 727.

${ }^{120}$ Id. at 728. Similarly, in State v. Tronchin, 539 A.2d 330 (N.J. Super. Ct. App. Div. 1988), the victim was raped after accepting the defendant's offer to drive her home after work when her regular ride failed to show up. Instead of taking her home, the defendant drove the woman to a dark and deserted park. When "she demanded to be taken home, telling defendant that she would walk if necessary," he replied, "I [would] hate to see what [those white boys out there] will do to you." Id. at 331 (alteration in original) (upholding the defendant's conviction on second degree sexual assault and reversing his conviction on kidnapping and first degree sexual assault).

121 See Commonwealth v. McColgan, 579 N.E.2d 182, 183-84 (Mass. App. Ct. 1991) (describing how a cab driver took a woman to her home, returned the next night, entered through a window and raped her); Salinas v. Fort Worth Cab \& Baggage Co., 725 S.W.2d 701, 703 (Tex. 1987) (allowing the victim's children to recover damages after witnessing the rape of their mother by a cab driver).

122 See Taxi Driver Jailed for Rape in Cab. THE INDEPENDENT (London), July 23, 1992 , at 4 . The driver-rapist in the case testified that sex with passengers was a "perk 
the physical features of a cab itself, such as driver-controlled doorlocking mechanisms, may facilitate an assault. So argued a woman, raped by her cab driver and several of his friends, in a civil action against the cab company's insurer. Ms. Gonzales, the victim, asserted that:

(1) [the cab driver] used his position as a cab driver to select his victim, (2) she was abducted in the taxi, (3) the locking mechanism of the taxi prevented her escape, and (4) the lights and horns of the taxi were used to signal [the driver's] accomplices. ${ }^{123}$

The court found that because the rape did not occur inside the cab, the taxi's role in the rape was "merely incidental" and thus not included within insurance coverage for injury arising out of the use of the vehicle. ${ }^{124}$

There have been a variety of attempts to prevent injuries arising out of the use of a car. One approach is self-help. Training exercises in women's self-defense classes now use realistic "bus stop' rape scenarios. ${ }^{125}$ There have also been institutional responses. The Toronto Transit Commission now permits bus drivers to drop off female passengers between designated stops after nine p.m., but does not allow any male passenger off at the same time. ${ }^{126}$

Other solutions are market-oriented. In response to the high number of assaults occurring in unlicensed "mini-cabs" in Britain, a new taxi company, Ladycabs, has emerged. Women-owned and -operated, Ladycabs uses only women as drivers and picks up only women, children, and escorted men as passengers. ${ }^{127}$ This development has equal applicability to Part I of this Essay, as it turns out that Ladycabs are not only used by women for their own travel

of the job." Id.

${ }_{123}$ Allstate Ins. Co. v. Motor City Cab Co., No. 83-1195 (6th Cir. Mar. 16, 1984) (LEXIS, Genfed library, Courts file).

${ }^{124}$ Id.

${ }^{125}$ Pamela King, Women and Men: Sexual Violence and Its Aftermath, PsYcHOL. TODAY, Sept. 1989, at 70, 71.

${ }^{126}$ See Eric Dowd, Bus Stop Order Cuts Risk of Rape, THE TIMEs (London), May 13, 1991 , at 11.

127 See Alice Thomson, The Dangers of Lifts from Strangers, THE TIMEs (London), July 24,1991 , at 12 (discussing Ladycabs's problems with the British Equal Opportunities Commission, which will not allow Ladycabs to advertise for exclusively women drivers). This aspect of entrepreneuralism has recently emerged in Beijing. See FYI, BEIJING SCENE, June 15-July 12, 1995, at 2 (asking women if they have found themselves "on an unlit street at night apprehensive at the thought of being harassed by a cabbie" and offering "a list of female drivers to be paged on just such an occasion"). 
safety but also to secure substitute chauffeur services; forty percent of the company's passengers are children being picked up from school. ${ }^{128}$

The dangers of public transportation reintroduce the class advantages of automobile ownership. In arguing that late night workers in Canada should be guaranteed safe passage home as a condition of employment, Elizabeth Aird points out that the "random" victims of late night assaults at bus stops are not really random. Women taking buses or subways late at night are likely to share certain class-related characteristics:

If she's taking transit after midnight, it's probably safe to assume she doesn't have a car. If she can't afford a car, chances are that she's a non-union employee. ... It's easy for a predator to find victims when he knows that a group of shift workers are getting off work at the same time.... Women at risk-and non-white Canadians, for instance, ... often take the graveyard gas station and convenience store jobs that no one else will take .... ${ }^{129}$

\section{Riding as Consent}

The danger of riding in cars combines both physical and legal harm. Cars are dangerous not only because women get raped in them, but also because accepting a ride in a man's car or offering to give a man a ride in her own car is often taken as a proxy for consent to subsequent sex. Thus cars provide not only the opportunity for rape, but the defense as well. Recall that from the start, the car-the "boudoir on wheels"-was regarded as an inevitable site for sexual encounters.

Of course, the mere availability of a private location says nothing about whether either party has agreed to engage in sexual conduct. Nonetheless, simply being in a car like such other types of conduct as dating, having a drink, or knowing one's attacker is commonly accepted as evidence of consent to sex. The structure of rape law permits the inference of consent from a woman's conduct to trump the evidence of nonconsent from such statements as "no," "I don't want to," or "don't." Rape law abandons the usual standards for determining criminal culpability (the assumption of the victim's innocence, the requirement of mens rea) and instead

${ }^{128}$ See Anne McFerran, The Cabbies Who Won't Be Taken for a Ride, THE TIMES (London), Feb. 9, 1992, at 1.

${ }^{129}$ Elizabeth Aird, Late-Shift Workers Should Be Guaranteed Safe Passage Home, VANCOUVER SUN, Dec. 10, 1992, at B1. 
mimics the social expectation of women as sexual provocateurs, controlling the dynamics of any social encounter. ${ }^{130}$

To grasp the durability of this phenomenon we might return to a 1905 Ladies' Home Journal advice column. A young woman asked what she should do "when a man persists in holding your hand in spite of all that you can say?" The answer: "No man ... would refuse to release your hand if you asked him as if you meant it."131 The reply indicates that if the man does not release her hand, the fault is hers, not for failing to say no, but for failing to mean no.

What then does a woman "really mean" when she accepts a ride from a man? A 1947 University of Michigan co-ed was raped by a fellow student after he dragged her into the back seat of his car. Both students were suspended, the woman because her conduct "was a credit neither to herself nor to the university." 132

And the legal significance of this social meaning? In addition to damaging one's reputation with university administration, getting into a man's car or inviting a man into hers puts a woman's credibility at risk at every step of the way in any subsequent rape prosecution. The presence of a car in a rape case diminishes the victim's credibility in three specific ways: First, the car makes it more likely that victim and attacker are not strangers; second, the victim is less likely to resist; third, the car prompts the cultural association with sexual conduct.

\section{Relationships Between Victim and Attacker}

Virtually all studies of rape conclude that " $[t]$ he relationship of victim and offender and the circumstances of their initial encounter appear key to determining the outcome of rape cases." 133 The victim's knowledge of the rapist influences whether the woman reports a rape, ${ }^{134}$ whether the police pass the case on for prosecu-

${ }^{130}$ In analyzing why rape remains underreported, underprosecuted, and underconvicted, Lynne Henderson contests the "unexamined belief that men are not morally responsible for their heterosexual conduct, while females are morally responsible both for their conduct and for the conduct of males." Lynne Henderson, Rape and Responsibility, 11 LAw \& PHIL. 127, 130-31 (1992).

${ }^{131}$ BAILEY, supra note 96, at 88 (quoting The Lady from Philadelphia, LADIES' HOME

J., July 1905, at 35).

132 Id. at 91.

133 SUSAN ESTRICH, REAL RAPE 18 (1987).

${ }^{134}$ See Robin WARSHaW, I NEVER Called IT RAPE 62 (1988). 
tion, ${ }^{135}$ whether prosecutors charge the alleged rapist, ${ }^{136}$ and whether juries convict. ${ }^{137}$

"Knowing" a rapist refers not to some long term relationship but simply to "voluntary initial encounters." Thus if a woman consents to

any connection with a man-developing a friendship with a male colleague or superior at work, accepting a date, going to a bar or a party and talking with a man (i.e., making a stranger a nonstranger through conversation), agreeing to drive a man she has just met to his home, allowing a man she just met to drive her home ... a presumption arises that she subsequently consented to sexual contact during the incident in question. ${ }^{138}$

In several states the law directly incorporates this presumption by reducing the degree of the felony in cases in which the rapist was a "voluntary social companion." 139

Thus in State $v$. Smith, ${ }^{140}$ the credibility of the victim was up for grabs the moment she offered William Kennedy Smith a ride home from a bar. Coercion? She drove herself to the scene of the crime. In addition, the circumstances under which Kennedy and the victim met (over drinks in a bar) made her all the more unsympathetic. It is tough business to rehabilitate at trial a woman who hangs out in a bar and leaves with a man. ${ }^{141}$ Because talking

135 See id.

${ }^{136}$ See Wallace D. Loh, The Impact of Common Law and Reform Rape Statutes on Prosecution: An Empirical Study, 55 WASH. L. REV. 543, 605, 621 (1980).

${ }^{197}$ But see Gary D. LaFreE, Rape ANd Criminal Justice: The Social ConSTRUCTION OF SEXUAL ASSAULT 202 (1989) (reporting study results which find that whether the victim and the rapist knew each other was not statistically significant in terms of trial outcome).

${ }^{198}$ Beverly Balos \& Mary Louise Fellows, Guilty of the Crime of Trust: Nonstranger Rape, 75 MINN. L. REV. 599, 605 (1991) (emphasis added) (arguing that relations between nonstrangers should be considered confidential relationships, subjecting each party to a heightened rather than reduced duty of care toward the other).

${ }^{139}$ See, e.g., DEL. Code ANN. tit. 11, \$§ 773-775 (1987 \& Supp. 1994) (implying that a person is guilty only of third degree unlawful sexual intercourse if the victim was the defendant's voluntary social companion).

${ }^{140}$ WASh. Post, Dec. 12, 1991, at A1 (Fla. Cir. Ct. Dec. 11, 1991).

${ }^{141}$ This puts aside the attention given to other pieces of evidence or things, such as the color and brand of the complainant's underclothes: "[B]lack and blue bra and Victoria's Secret panties." David Margolick, Credibility Seen As Crux of Celebrated Rape Trial, N.Y. TIMES, Dec. 1, 1991, at 24. Such evidence demonstrates again that the cultural meaning of a thing has legal significance. Yet the sexualized glamour of a product-whether cars or underpants-conceals its unexpected danger for women. Print advertising regularly sells fancy lingerie to women urging the purchase for the consumer's own satisfaction. 
to a man in a bar counts as a voluntary initial encounter, it deprives the victim of the testimonial "benefit" of being raped by a total stranger. ${ }^{142}$

Defendants-and the occasional court-may be alert to the legal significance of the social understandings that attach to women who socialize in bars and drive away with men. Consider a 1980 Michigan case, People v. Mustafa, ${ }^{143}$ in which the defendant and the victim left a bar together in her car. A short time later the police, responding to radio reports of screams, came upon Mustafa in a field with his pants down, lying on top of the victim: ${ }^{144}$

The complainant was screaming that she was being raped; she had a small abrasion underneath her lip, her hair was in disarray and her clothing was partially off; the keys to complainant's car were found in defendant's pocket. ${ }^{145}$

Mustafa was convicted, but on appeal argued that the judge improperly admitted evidence of his prior similar act. Under Michigan law, similar acts are admissible only when there are "sufficient similarities in the cases such that they tended to show a plan or scheme to orchestrate the events surrounding the rape so that the complainant could not show nonconsent and the defendant could escape punishment."146 In Mustafa, the Michigan Court of

In contrast, consider the juror sitting in the St. John's rape case who wore a t-shirt in court reading "Unbutton My Fly." Friends have informed me that this is a Levi's logo for its 501 jeans. But surely the words "Unbutton My Fly" represent something more than product identification. For a discussion of the St. John's rape case, see infra notes $169-79$ and accompanying text.

${ }^{142}$ Socializing near alcohol leads to the inference that a woman is consenting to sex. Because drinking lowers inhibitions, a woman who drinks on her own is preemptively lowering her own resistance and implicitly signaling "yes."

143291 N.W.2d 130 (Mich. Ct. App. 1980).

14 See id. at 132.

${ }^{145}$ Id. at 131-32 (emphasis added).

${ }^{146} \mathrm{Id}$. at 132. Under the proposed amendments to the Federal Rules of Evidence, evidence of similar crimes in sexual assault cases and evidence of similar acts in civil cases concerning sexual assault would be admissible. See Proposed Fed. R. Evid. 413(a), Pub. L. No. 103-322, § 320935, 108 Stat. 1796, 2136-37 (1994) ("In a criminal case in which the defendant is accused of an offense of sexual assault, evidence of the defendant's commission of another offense or offenses of sexual assault is admissible, and may be considered for its bearing on any matter to which it is relevant."); Proposed Fed. R. Evid. 415(a), 108 Stat. at 2137 ("In a civil case in which a claim for damages or other relief is predicated on a party's alleged commission of conduct constituting an offense of sexual assault ... evidence of that party's commission of another offense or offenses of sexual assault . . . is admissible and may be considered as provided in Rule 413 ... of these rules.”). But see James S. Liebman, Proposed 
Appeals held that sufficient similarities existed between the defendant's prior act and present acts:

[T] he defendant-by selecting victims from bars late in the evening under circumstances where the victims would be voluntarily driving to a secluded spot in the victim's car under his direction and by attacking the victim's moral standards and chastity upon a charge of rape-demonstrated a similar scheme to orchestrate the events surrounding the rape to prevent a showing of nonconsent. ${ }^{147}$

In other cases, rape defendants deliberately flirted or "schmoozed" with their victims in order to trigger the presumption that prior contact between a man and a woman negates the likelihood of coercion in any subsequent sex. In People $v$. Oliphant, ${ }^{148}$ the defendant gave each of his several victims a slip of paper with either his address or his license plate number before driving them to secluded spots for the rape. This way the woman would have her rapist's name in her purse for purposes of any subsequent investigation. ${ }^{149}$ Oliphant would also stop for gas several times so that the victim would be seen in the car with him. On one occasion, he went to the local police station after raping his victim and told the police that he had just had intercourse with a woman and afterwards had told her that she smelled bad. He then explained that because she got angry over his remark he was concerned that she might accuse him of rape. He was actually present at the police station when the rape report came in. ${ }^{150}$

Evidence Rules 413 to 415-Some Problems and Recommendations, 20 DAYTON L. REV. 753, 762 (1995) (arguing that these proposed rules are "overbroad, potentially unconstitutional, and poorly drafted").

147 Mustafa, 291 N.W.2d at 132 (emphasis added). Similarly, in Williams v. State, 110 So. 2d 654 (Fla. 1959), the defendant hid in the back seat of his victims' cars on the pretense of napping in what he mistakenly believed to be his brother's car. Here too the court admitted similar fact evidence because "it was relevant to meet the anticipated defense of consent." Id. at 663; see also State v. Esposito, 471 A.2d 949, 953 (Conn. 1984) (admitting evidence of a similar prior sexual assault to show a common plan and noting that "the circumstances under which the victims were sexually assaulted were such as to make it easier for the defendant to claim later that there had been consent"); Jackson v. State, 538 So. 2d 533, 535 (Fla. Dist. Ct. App. 1989) (holding that evidence which showed that the defendant claimed that his previous sexual assault victim consented and offered him sex for money was properly admitted to suggest a scheme designed to establish the victim's consent).

148250 N.W.2d 443 (Mich. 1976).

149 See id. at $448-49$.

${ }^{150}$ See id. at 446. 
The relation among bars, cars, and rape combined in particularly ironic fashion in Aldoupolis $v$. Commonwealth. ${ }^{151}$ In that case the victim met her five attackers in a bar and drove with them in her car to a wooded area where each man had sexual intercourse with her while the others jumped on her car. The men were indicted for rape and for malicious destruction of property; each pled guilty. ${ }^{152}$ The trial judge accepted their pleas and then, describing the attacks as "a consensual sexual adventure that went off track," he suspended their sentences. ${ }^{153}$ Following "four days of public outrage," the judge then revoked the suspended sentences. ${ }^{154}$

After several rounds of appeals, the Supreme Judicial Court of Massachusetts held that the sentences had been improperly revoked. ${ }^{155}$ The men were retried and this time each pled not guilty. The verdict was split: the men were acquitted of rape but convicted of damaging the car. In a newspaper opinion piece following the trial, columnist Ellen Goodman explained the two verdicts by hypothesizing that a car makes a better client than a woman:

[The car] was not penalized for being unable to testify at the trial. Nor did anyone in the courtroom bring up the automobile's private history or reputation.... In addition, cars cannot be judged harshly for frequenting a bar, although occasionally they guzzle gas. ${ }^{156}$

Aldoupolis then sued Goodman for defamation. Goodman won on the grounds that her column stated only her opinion regarding the fact of rape; the court noting her use of the "rhetorical device of personification to make an automobile a person and by an adroit cadence of parallel sentences compar[ing] the favorable treatment of a motor vehicle to the shabby treatment of women in rape cases. ${ }^{\text {157 }}$

151435 N.E.2d 330 (Mass. 1982).

132 See id. at 331.

${ }^{153}$ Ellen Goodman, Assault on a . . Car, WASH. POST, July 26, 1983, at A17.

${ }^{154} \mathrm{Id}$. The revocations were based on the opposition to the sentences by the district attorney, the public interest, and their questionable legality in view of a state statute prohibiting suspended sentences for certain offenses. See Aldoupolis, 435 N.E.2d at 331 .

${ }^{155}$ See Aldoupolis, 435 N.E.2d at 338.

${ }^{156}$ Goodman, supra note 153 , at A17.

${ }^{157}$ Aldoupolis v. Globe Newspaper Co., 500 N.E.2d 794, 797 (Mass. 1986). 


\section{Victim Resistance}

In addition to any prior "relationship" between the victim and the rapist, evidence of the victim's resistance also influences the outcome in rape cases. The more she resists, the more likely the case will be charged, prosecuted, and won. But a victim trapped in a moving car, locked in a van, or driven to a deserted park may be far less likely to resist so as not to risk additional physical injury. ${ }^{158}$ She is already confined and cannot run away. ${ }^{159}$ Resistance may well intensify her injury. Nonetheless, the failure to resist sufficiently is often taken as proof of consent. Thus in People v. Hunt, ${ }^{160}$ the California Court of Appeals overturned a rape conviction on grounds that the victim "never clearly articulated any lack of consent," despite "substantial evidence from which the jury who saw the witnesses and observed their demeanor, could reasonably conclude that [the victim's] fear was genuine and that defendant's conduct in ignoring her plea not to be driven into the hills carried an implied threat that [she] had only the choice of submitting or suffering great bodily harm. ${ }^{n 161}$ The problem of resistance is compounded by the familiarity, however brief, between driver and passenger. Thus proof of resistance appears

particularly critical in determining the outcome of [rape] cases where the initial encounter between the victim and her assailant was voluntary (she got into the car willingly, or invited him in). In voluntary encounter cases, the probability of indictment was only thirteen percent where little victim resistance was used; it jumped to fifty-three percent where resistance was substantial. ${ }^{162}$

${ }^{158}$ See, e.g., People v. Blake, 474 N.E.2d 892, 896 (Ill. App. Ct. 1985) (rejecting the defendant's argument that the victim's testimony was not credible because she "never attempted to escape while the [defendant's] van was stopped at traffic lights" and finding that under the circumstances "the victim's failure to attempt to escape was understandable and reasonable"); State v. Rusk, 424 A.2d 720, 728 (Md. 1981) (rejecting the defendant's argument that the victim consented by insufficiently resisting his advances). For a discussion of Rusk, see supra notes 116-20 and accompanying text.

${ }^{159}$ See Bowell v. State, 728 P.2d 1220, 1225 (Alaska Ct. App. 1986) (finding that one rape defendant assisted the other "by driving the car, without slowing the rate of speed, to prevent [the victim's] escape").

${ }^{160} 139$ Cal. Rptr. 675 (Cal. Ct. App. 1977).

${ }^{161}$ Id. at 679 (holding that the defendant's prior rape conviction was improperly admitted as evidence of the victim's subjective fear because the victim did not know about that prior conviction when she had to decide whether she would consent to sex).

${ }^{162}$ ESTRICH, supra note 133 , at 19 (emphases added). 
In the rare case, a woman who voluntarily enters a car may be regarded as credible when she testifies at trial. In Helton $v$. State, ${ }^{163}$ the court acknowledged that ${ }^{4}$ [a]lthough the victim got in appellant's car voluntarily, once he refused to let her out of the car and held her against her will, a kidnapping occurred. ${ }^{p 164}$ It is worth noting that in Helton the defendant attacked a Georgia Bureau of Investigation agent whose car broke down in an ice storm a few miles from her apartment. After resisting his initial attack, she hit him on the head with a flashlight, causing his car to veer off the road. The agent ran to a nearby house and asked the occupant to call the police. The agent heard shots and, looking out the window, "observed a man[,] later identified as George Neal[,] with a pistol pointed at [the defendant]."165 The agent went outside, drew her pistol, and informed the defendant that he was under arrest. The defendant continued to approach the agent at which point Neal said, "Buddy, if you do it, I will drop you like a rock." 166 I include these details to demonstrate the extraordinary levels of resistance and corroboration necessary to validate the victim's side of the story when she accepts a lift from a man.

\section{Cars and Sex}

The voluntary social encounter and resistance aspects are intensified by the third factor eating away at victims' credibility in car cases: social understandings about sex in cars. Hitchhikers provide a good example. They voluntarily get into the cars of strangers and are commonly understood to be "asking for it." 167 In Britain, a man who raped a hitchhiker was fined but not jailed because the judge held that his teenage victim was "guilty of contributory negligence" for hitchhiking alone. ${ }^{168}$

163305 S.E.2d 592 (Ga. Ct. App. 1983).

${ }^{164}$ Id. at 593; see also People v. Blake, 474 N.E.2d 892, 895 (Ill. App. Ct. 1985) (holding that the victim's testimony that she was forced to enter the defendant's van at knifepoint was sufficient to support a kidnapping conviction, "[s]ince confinement in an automobile satisfies the statutory requirement of secret confinement").

${ }^{165}$ Helton, 305 S.E.2d at 593.

${ }^{166} I d$.

${ }^{167}$ See Bowell v. State, 728 P.2d 1220, 1225 (Alaska Ct. App. 1986) (quoting a rape defendant who told his victim that "[1]ittle girls shouldn't be out hitchhiking in the middle of the night . . . unless they're asking for something").

${ }^{168}$ Reuters North European Service, Jan. 7, 1982, available in LEXIS, News Library, Wires File; Reuters North European Service, Jan. 21, 1982, available in LEXIS, News Library, Wires File. 
The connection between cars and consent was highlighted by two recent and much publicized rape trials. In March 1990, five students at St. John's University were charged with rape. One of the defendants, Michael Calandrillo, offered another St. John's student a ride home from school. ${ }^{169}$ On the way home, Calandrillo told the woman that he had to stop at his house to pick up some gas money. ${ }^{170}$ She accompanied him inside the house, which he shared with other members of the St. John's lacrosse team. ${ }^{171}$ At trial the woman testified that Calandrillo pressed several drinks of fruit juice and vodka upon her and she became drunk. During the next several minutes, she was forced to perform oral sex on Calandrillo and was sodomized and fondled by five or six other housemates. ${ }^{172}$ She was then carried to a neighboring house where the abuse continued. She was finally driven home after one of the housemates called a stop to what he was witnessing. ${ }^{173}$

The defendants argued that the woman had consented, either expressly or implicitly, to all the sex that had taken place and that her conduct on the day of the rape and during the investigation was inconsistent with any story of coercion. ${ }^{174}$ The argument focused in part on the woman's delay in reporting the rape. In New York, as in most jurisdictions, a woman's failure to report a rape promptly is considered inconsistent with her claim of nonconsent. Indeed, a jury may consider a woman's delay in reporting as "virtual selfcontradiction. ${ }^{\text {175 }}$ In this case, the victim waited four days before

${ }^{169}$ See Beth Holland \& Peg Tyre, Assailing Her Credibility; St. John's Cross-Exam, NEWSDAY (N.Y.), June 19, 1991, at 5, available in LEXIS, News Library, Arcnws File.

${ }^{170}$ See Verdict: Not Guilty: Jury Clears 3 Liars in St. John's Sexual Abuse Trial, NEwsDAY (N.Y.), July 24, 1991, at 3, 18, available in LEXIS, News Library, Arcnws File.

${ }^{171}$ See Peg Tyre, 18 Witnesses Later, No 1, Clear Picture, NEwSDAY (N.Y.), July 15, 1991, at 8, available in LEXIS, News Library, Arcnws File.

172 See Holland \& Tyre, supra note 169 , at 5 . For a discussion of the practice among fraternity brothers of the pervasive use of alcohol to obtain sex from women, see Patricia Yancey Martin \& Robert A. Hummer, Fraternities and Rape on Campus, RAPE and Society: Readings on the Problem of Sexual Assault 139 (Patricia Searles \& Ronald J. Berger eds., 1995).

${ }^{173}$ See Edward Frost, Inside Stories Reveal Details of Sex Case, NAT'L L.J., June 24, 1991, at 8; Peg Tyre \& Beth Holland, Jury Hears Tale of Terror: St. John's Accuser Testifies, NEwSDAY (N.Y.), June 18, 1991, at O5, available in LEXIS, News Library, Arcnws File.

174 The defense attacked the woman's credibility by suggesting that she had consented to "at least some sexual contact with at least one of the [defendants]." See Peg Tyre, Woman's Credibility Pivotal, NewSDAY (N.Y.), July 25, 1991, at 30, available in LEXIS, News Library, Arcnws File.

${ }^{175} 4$ JOHN WIGMORE, EVIDENCE § 1135, at 298 (rev. ed. 1972 \& Supp. 1995) (noting that some states believe this doctrine is based on outdated and illegitimate 
confiding in a nun at the University Campus Ministries and waited nine days longer before reporting the assault to the police. ${ }^{176}$

Yet it is not uncommon for a woman to wait before telling anyone that she has been raped. Because claims of rape by an acquaintance are met with extra suspicion, women may be especially reluctant to report the event when the rapist is not a complete stranger. One reason for the delay in the St. John's case may have been the victim's accurate perception that accepting a lift from one of her attackers would discredit her story. Consider the defense counsel's question on cross-examination: "Didn't you say to [a university official], 'It's no big deal. It's all right. I shouldn't have got in the car. I shouldn't have accepted the ride[?]" 177 In contrast, the prosecution understood that its task was to distinguish accepting a ride and a drink from the qualitatively different act of consenting to sex. In his closing arguments, Assistant District Attorney Peter Reese asked the jury, "Did this woman consent to group sex because she asked for a ride home?" 178 The jury acquitted all five defendants. ${ }^{179}$

presumptions). In New York, a victim's failure to make a prompt complaint entitles the defense to request the following jury instruction: "The defendant contends that the failure of [name of victim-witness] to [identify] until [state hours, days, weeks, months] following the events of [date and time] should be considered by you in assessing the credibility of [name of victim-witness]." 1 NEW YORK JURY INSTRUCTIONS, CRIM. CJI 7.27, at 306 (1983). See generally Dawn M. DuBois, Note, A Matter of Time: Evidence of a Victim's Prompt Complaint in New York, 53 BROOK. L. REV. 1087, 1087-88 (1988) (arguing that New York's prompt complaint doctrine ignores the victim's subjective experience of rape).

${ }^{176}$ See Beth Holland, Nun Takes the Stand, NewSDAY (N.Y.), June 3, 1991, at 8, -available in LEXIS, News Library, Arcnws File; Peg Tyre, St. John's Rape Trial Set to Start, NEwSDAY (N.Y.), May 7, 1991, at 102, available in LEXIS, News Library, Arcnws File.

${ }^{177}$ Holland \& Tyre, supra note 169 , at 5 (quoting Stephen Scaring, an attorney for one of the defendants) (emphasis added).

${ }^{178}$ Peg Tyre, Summing Up in St. John's Case; Closing Arguments Presented in Sex Abuse Trial of 3 from Bethpage, NEwSDAY (N.Y.), July 17, 1991, at 22 (emphasis added), available in LEXIS, News Library, Arcnws File. Reese also asked the jury if the victim consented to group sex " $[\mathrm{b}]$ ecause she talked about sex? Because she accepted a soft drink that turned out to have vodka in it? Did this mean she consented to group oral sex?" Id. (alteration in original).

${ }^{179}$ Jurors later explained that it was not the ride alone that made them unsympathetic to the victim. They didn't think a raped woman would act so "belligerent" on the stand. In addition, the jurors thought the victim might have made it all up after she learned that Calandrillo had a real girlfriend. Once again scorn reappeared as the all-purpose explanation for why women ever say bad things about men. See Sex on Trial: It Will Take Even More Courage Now for Abused Women to Come Forward and Seek Justice, NEwSDAY (N.Y.), July 25, 1991, at 60, available in LEXIS, News Library, Arcnws File. There was also the suggestion of sympathy for the defendants, who were 
Getting into a car also played a role in the case of Tyson $v$. State. ${ }^{180}$ Former boxing champion Mike Tyson, a guest celebrity at the Miss Black American Pageant, called Desiree Washington, a contestant, at her hotel and invited her to go riding with him in his limousine. Despite the late hour she agreed. This is where Tyson's consent defense began. Of course Tyson understood that Ms. Washington was agreeing to sex. That's what riding in a limo late at night means-especially with Mike Tyson. ${ }^{181}$ Tyson's defense counsel asked Ms. Washington what she thought would happen. "You never met Mr. Tyson before July 18, but within minutes he's hugging you and asking you out? . . . You willingly drove to his hotel? You willingly went to his suite? You willingly sat on the bed? ${ }^{n 182}$ In her responses, Ms. Washington came across as naive but honest, ${ }^{183}$ and Tyson was convicted.

just college kids after all with a lot to lose. Thus it was not only how the young woman got there, but also where she was that added something more to the mix-an informal fraternity of sorts, where expectations of sex are assumed to be high and regard for consent to sex apparently low. See Martha T. McCluskey, Privileged Violence, Principled Fantasy, and Feminist Method: The Colby Fraternity Case, 44 ME. L. REV. 261, 296 (1992) (discussing a fraternity at Colby College which encourages and practices violence against women).

${ }^{180} 619$ N.E.2d 276 (Ind. Ct. App. 1993).

${ }^{181}$ See id. at 296. Tyson's defense combined consent with a theory of assumption of sexual risk. His lawyers called 11 other pageant contestants who testified that Tyson had been "lewd," "raunchy," "rude," "disgusting," and "creepy" in his dealings with them. See Claude Lewis, No Tears for Tyrranical Troubled Mike Tyson, HousToN CHRON., Feb. 13, 1992, at 19. The point of their testimony was to create a kind of sexual caveat emplor: any woman who went out with Tyson had to know what he wanted. See Earl Gustkey, Tyson Case Will Go to Jury Today, L.A. TIMES, Feb. 10, 1992, at C1. Tyson's defense counsel summarized this for the jury: "Mr. Tyson concedes that sex was on his mind." Jury Deciding Fate of Boxer Tyson, DALLAS MORNING NEws, Feb. 11, 1992, at 3A (quoting Vincent Fuller, Tyson's attorney).

The argument puts the issue of women's consent in a more precarious position than usual by fixing the man's reputation as the baseline from which indicia of consent are determined. Determination of consent is measured not by what the woman does or says, but by whatever the woman knows about the man. Under this reasoning, the more open and notorious a man's sexual aggressiveness, the less evidence is necessary to establish the victim's consent. Is he so famous for sexual behavior that women must take judicial notice of what he is making no bones about? The "Bad As I Can Be and Everyone Knows It" defense would appear to make common social acts, like riding in a car, more rather than less relevant because the defendant's reasonable belief defense is very much concerned with what the women knew prior to the rape itself.

${ }^{182}$ Lisa Ryckman, Accuser Testifies Tyson's Pleasant Manner 'Fooled' Her, PHIL. INQUIRER, Feb. 1, 1992, at A4 (emphasis added); see also Michael Madden, Defense Can't Take Offensive, Boston GLOBE, Feb. 1, 1992, at 33, 35 (reporting that Tyson's cross-examination of Ms. Washington appeared to backfire).

${ }^{18 s}$ See Madden, supra note 182 , at 35. 
The Tyson case puts an odd gloss on the traditional role of the chauffeur. Much was made in the early days of driving about the simmering relationships between upper-class women and their working-class chauffeurs (the chauffeur was master of his lady's destination, controlling the "pleasure car," as early automobiles were often called), and about the unspoken relationships between discreet chauffeurs who did not reveal the destinations of their male employers. ${ }^{184}$ Here, however, the chauffeur was a middle-aged, female, off-duty junior high school counselor who testified for the prosecution regarding the victim's distraught appearance and behavior after she returned alone to the limo to be driven back to her hotel. ${ }^{185}$

In thinking through the connections between consent and credibility, scholars have begun to question not only the facts but also the process through which facts or evidence are produced. Recent work using conversational analysis, part of the "sociology of talk," explains how a victim's credibility is dismantled linguistically. In analyzing three rape trial transcripts, Gregory Matoesian argues that "because talk is a central device of legitimization and social control, male hegemony is largely produced and reproduced through [talk]." ${ }^{n 66}$ Each of Matoesian's rape trial transcripts involved a car: hitchhiking, meeting at a bar and driving off together, and a pick-up at a gas station. He explains the selection of these cases as "fit[ting] into the category of date and acquaintance type rapes, making the current data set representative of the vast majority of rapes." 187 Matoesian explains that

${ }^{184}$ For a cheerful account of the history of chauffeurs and the intricacies of chauffeur culture (with no mention of sex at all), see LORD MONTAGU OF BEAULIEU \& PATRICK MACNAGHTEN, HOME JAMES: THE CHAUfFeUR IN THE Golden AGE OF MOTORING (1982).

${ }^{185}$ See Phil Berger, Tyson's Driver Says Woman Was Dazed, N.Y. TIMEs, Feb. 2, 1992, $\S 8$ (Sports Sunday), at 1,2 . The chauffeur testified that Ms. Washington appeared shocked, dazed, and disoriented. See id. at 1 . She was also prepared to testify that while bringing Tyson's bags to his room the previous day, Tyson grabbed her, tried to kiss her and exposed his genitals. See Wallace Matthews, Tyson Was 'Begging': Driver Tells of Telephone Call, Boxer Exposing Himself to Her, NEWSDAY (N.Y.), Feb. 2, 1992, at 3, available in LEXIS, News Library, Arcnws File. Judge Patricia Gifford excluded the testimony, however, because the chauffeur did not press charges against Tyson for this conduct. See Berger, supra, at 2.

${ }^{186}$ Gregory M. MATOEsian, Reproducing Rape: Domination Through Talk IN THE COURTROOM 34 (1993) (discussing the interaction between social structure and conversation analysis in the context of rape trials).

${ }^{187} \mathrm{Id}$. at 58. See generally id. at 98-188 (discussing talk and power in rape trials). 
not only is the ideological supremacy of male hegemony threaded throughout victim cross-examination, but the talk that drives and structures such ideology in the first place is differentially and asymmetrically distributed across social position. Defense attorneys ask questions; victims answer questions. Defense attorneys set the agenda; victims follow the agenda. ${ }^{188}$

The power and logic of this argument is revealed in the following exchange between a victim (" $V$ ") and a defense attorney ("DA"):

DA: When you left the parking lot that night [did you] know this [Mr.] Winwood[']s first name at that point?

V: Yes.

DA: [Did you] know his last name? when you left the parking lot that night?

V: No.

$\ldots$

DA: [Did you] know where Winwood was from? when you left the parking lot that night?

V: $\quad$ No.

DA: [Did you] know where Winwood was work? [sic] when you left the parking lot that night?

V: No.

DA: Did he force you to get [into] his [automobile] in the parking lot?

V: No.

DA: How [did you] wind up in his [automobile]?

V: $\quad$ I got in.

DA: W[hy?]

V: Because he said we were going to [a] party at [his] - friend['s] ... house.

DA: [But you] didn't [know] his last name, where he worked or where he was from correct?

V: Yes.

DA: You didn't know [any]thing about him, [did you]?

V: $\quad$ No. ${ }^{189}$

Matoesian deconstructs the exchange linguistically, explaining how such techniques as sequential poetics ("Did you know . . ."), blamerhetoric devices ("... did you?), and three-part lists ("his name, where he worked or where he was from") work to "transform[] the [victim's] experience of sexual violence into consensual sex."190

${ }^{183}$ Id. at $34-35$.

${ }^{189} \mathrm{Id}$. at $171-72$ (emphasis omitted).

${ }^{190} \mathrm{Id}$. at 170. 
Yet for our purposes the transcript also works at a nonlinguistic level, as we come to realize that this victim is a nonfictional Thelma, taken out to the parking lot to be raped without knowing very much about the handsome cowboy at all.

\section{CONCLUSION}

What then are we to make of the complicated relationships between women and cars? Despite the advertised glamour and the promise of freedom and fun, women's use of cars carries unexpected (or at least unadvertised) problems. We know that cars are dangerous places by virtue of their physical characteristics-cramped, immobilizing, portable space-and by virtue of the cultural connection between cars and sex. ${ }^{191}$

Yet "car talk" for women may not be a complete tale of subordination. A recent women's car repair manual challenges women drivers: "Is it worth sparing yourself the embarrassment as an intelligent woman of being forced to stand along the roadside next to your car waiting for help, dependent on someone else-only to discover later that the repair was so simple that you could have done it yourself?" 192 In addition to the pleasure and accomplishment of repair, women have begun to achieve satisfaction and success with their cars just as men do with theirs.

We might start with the gendered proposition of purchasing a car. Aware that women now buy half of all new cars and influence the selection of eighty percent of all car purchases, advertisers have begun to pitch advertising for particular cars-and not just vans or "mommy-wagons"-toward women consumers. ${ }^{193}$ Saturn ads, for

Questions about last name, residence, and place of employment constitute category-bound knowledge and obligations that a bona fide victim is held accountable for "owning." Because the [victim] only knows the rapist's first name and not the last, for example, the inference is strongly suggestive of a casual relationship, which in turn may be symbolic of casual sex.

Id. at 172.

${ }^{191}$ See David Arnold, Aggression Gets Wheels, Boston GLOBE, Dec. 23, 1992, at 17, 23 (noting that "[c]ars are advertised as offering power and machismo" and "are symbols of control").

${ }^{192}$ CH. STURTZ, THE WOMEN'S Basic AUTOMOTIVE HANDBOOK: BASIC CAR CARE \& MAINTENANCE INFORMATION FOR WOMEN WHO WANT TO TAKE RESPONSIBILITY FOR TheIr CARS at vii (1980). But cf. CLIFFORd AUSTIN \& CEC. BENNETT, PARDON ME, BUT YOUR CLUTCH Is SLIPPING! at viii (1972) ("This book is dedicated to those ladies who drive cars but have no mechanical knowledge whatsoever. . . . [It] is intended to be a friend in need when those minor things happen to frustrate and delay you, to make a fool of you and, in other ways, to embarrass you.").

${ }^{199}$ See Amy Harmon, Auto Firms Struggle to Tap Lucrative Women's Market, L.A. 
example, show real women (or at least models that look like real women) engaged in such unglamorous activities as unloading birdseed or bowling balls from their Saturns. In 1992 the marketing magazine Adweek reported an even more "revolutionary car marketing techniquen: using a woman as the driver of a car. ${ }^{194}$ Salesmen, notorious for treating prospective women customers condescendingly ("Bring your husband back with you and we'll talk seriously"), now make greater efforts to take women seriously. ${ }^{195}$

Compounding the traditional discourtesies inherent in the transaction, women have also paid more for their cars than white male purchasers. As Ian Ayres's work on discriminatory practices in new car sales reveals, the dealer's mark-up on the opening price (the figure which determines the final price) offered to white women and to all African-Americans has been significantly higher than the mark-up offered to white men. ${ }^{196}$ In response both to the insult and the economic injury, certain dealers, such as Saturn, now offer both courtesy and non-negotiable-thus presumptively fairer-sticker prices.

Women now sometimes drive, polish, and brag about their cars with the same intensity as do men. There are a few woman-owned car dealerships, ${ }^{197}$ women car designers, ${ }^{198}$ and women race-car

TIMES, June 19, 1992, at A1, A7 (describing the efforts of automakers to appeal to the increasing numbers of women who buy cars). Compare the disastrous case of the 1955 Dodge La Femme, available only in pink and lavender, which sold fewer than 1000 models, despite the matching purse, umbrella, raincoat, and boots. See id. at A1.

${ }^{194}$ Eric Hollreiser, Women and Cars, ADWEEk's MARKETINC WK., Feb. 10, 1992, at $14,18$.

${ }^{195}$ See id. at 15-18. Their efforts may be in response to women's concerns when buying cars. A survey of women buyers over 40 revealed that "reliability, performance, safety features, and price ${ }^{n}$ were the factors most influencing their purchase of a new car. Women $\mathcal{E}$ Wheels, LEAR's, Apr. 1994, at 44, 45.

${ }^{196}$ See Ian Ayres, Fair Driving: Gender and Race Discrimination in Retail Car Negotiations, 104 HARV. L. REv. 817, 827-33 (1991). Ayres and Siegelman's second study suggests that the mark-up for African-American men may be higher still. See Ian Ayres \& Peter Siegelman, Race and Gender Discrimination in Bargaining for a New Car, 85 AM. ECON. REv. 304, 304-05 (1995). Adding literal insult to economic injury, women car buyers are also treated worse than men. Women are frequently subjected to sexist remarks by car salesmen as well as refusals to help until "you bring your husband back with you." See FrANCES C. WHITTELSEY, WHY WOMEN PAY MORE: How TO AVOID MARKETPLACE PERILS at vii-viii (1993) (reporting that women pay higher prices for car repairs and auto insurance-despite their better driving records).

${ }_{197}$ See, e.g., Stephen Barr, Four Driving Forces: A Quartet of Women Who Are Making Their Mark in the Auto Industyy-and Heading for the Passing Lane, LEAR's CAR GUIDE, Apr. 1993, at 68, 68 (interviewing the first woman to be named Time magazine's Quality Dealer of the Year).

${ }^{198}$ See Heiman, supra note 11, at E1, E5. 
drivers. ${ }^{199}$ Women also use cars for business, such as real estate. $^{200}$ There is also evidence that women are becoming more aggressive in their driving habits. A recent study reported that "[ $t]$ heir crash and violation patterns contain more citations for failure to stop, failure to yield the right of way, and safe movement violations" than young men. ${ }^{201}$

Yet there is something unsettling about revising the car as icon and artifact if the revision means that women will simply duplicate male automotive behavior. My idea is not that hitchhiking women should start murdering the men who pick them up or that angry wives in cars should regularly run down their pedestrian husbands. ${ }^{202}$

Instead, we might shake the automobile loose from its gendered functions so that "reinventing the wheel" might be a good idea instead of a redundancy. ${ }^{203}$ Imagine, for example, automotive

${ }^{199}$ See Confessions of a Fast Woman, PUBLISHERS WKLY., July 27, 1992, at 55 (reviewing LESLEY HAZLETON, CONFESSIONS OF A FAST WOMAN (1992)).

${ }^{200}$ Cars or vans are also used in prostitution. See, e.g., Will Bennett, Red-Light Area May Get Official Approval, THE INDEPENDENT (London), July 20, 1994, at 3 (stating that in Utrecht customers arrive by car and select one of 40 women who operate out of parked vans), available in LEXIS, News Library, Curnws File; Barbara O'Brien, Prostitutes Keep on Truckin', BufFalo NEwS, Jan. 22, 1993 (noting that some prostitutes in Buffalo are completing their transactions in vans and rental trucks), available in LEXIS, News Library, Curnws File; Abigail Van Buren, Wife Thinks Siren Could Stop Trucker, CHI. TRIB., May 22, 1985, at C2 (relating a story of a prostitute "who drives a van with a waterbed in the back and who 'advertises' on her CB radio").

${ }^{201}$ John Barbour, U.S. Highway's-Fewer Drunks, More Women, L.A. TIMES, June 28, 1992, at A5 (reporting that young women are driving more often and at faster speeds than ever before and that women's drunk driving rates are declining slower than men's); cf. Craig v. Boren, 429 U.S. 190, 200-04 (1976) (striking down an Oklahoma statute that presumed that a correlation existed between the sex of a driver and the driver's propensity to drink and drive and finding that the statistical studies which supported this conclusion were inconclusive).

${ }_{202}$ See A Case of Sex and Death in Florida, NEwSwEEk, Jan. 20, 1992, at 6, 6 (reporting that Aileen Wuornos confessed to killing five men after posing as a hitchhiker).

${ }^{203}$ Thus the car may be joining ranks with other familiar icons whose once fixed positions within the culture are coming unglued as women challenge the uses to which their bodies, their images, and their labor have been put. Posters of naked women in company locker rooms are now sometimes understood as forms of sexual harassment instead of acceptable office decoration. See, e.g., Robinson v. Jacksonville Shipyards, Inc., 760 F. Supp. 1486, 1519 (M.D. Fla. 1991) (holding that condoning posting of nude pictures of women in a work environment may encourage sexually harassing conduct); Arnold v. City of Seminole, 614 F. Supp. 853, 863 (E.D. Okla. 1985) (finding that a poster of a naked woman in a police officer's locker which stated that women do not belong on the police force created a hostile environment). Similarly, motherhood, the mother of all icons, is up for grabs as single mothers, 
designs that take women's needs into account: shoulder harnesses that didn't smash women's breasts; floor pedals that took account of high heels; rear view mirrors that would allow the driver to see all of the passengers in the back seats. ${ }^{204}$

And why stop at wheels? Women might also reconsider or reinvent the space through which cars travel, taking back not only the night but the spaces in which we live and spend time: our homes, our streets, our neighborhoods. To some degree that larger project has already begun. As the gendered nature of space becomes more apparent and more vicious, women are contesting not only the accuracy, but the inevitability of the description. They. no longer accept fear, insult, and injury as inevitable in either private or public space. ${ }^{205}$

Imagine as well a reconfiguration of household labor with more fathers participating in domestic driving, and not only because Volvo is now marketing its cars as being sexy as well as safe. Changes in gender roles are putting new demands on old conceptions of the functions of zoning regulation. Women are now "out to work, ${ }^{206}$ and the same police power that has justified excluding day care from the suburbs is now being used to require it downtown. A number of municipalities are invoking land use planning to come to the aid of working mothers. Alert at last to the childcare concerns of working mothers (and their employers), San Francisco and Boston, for example, now condition building permits on real estate developers' promise either to provide on-site child care or to pay into a fund to support child-care centers elsewhere. $^{207}$ Seattle, Vancouver, and Hartford offer downtown

working mothers, and teenage mothers (to name only a few of the newer categories) challenge the once reliable idea and institution. See Carol Sanger, M Is for the Many Things, I S. CAL. REV. L. \& WOMEN's STUD. 15, 18 (1992).

${ }^{204}$ See Heiman, supra note 11 , at E1 (noting that " $[\mathrm{t}]$ oday's cars . . . are designed by men ... . [and] have been customized for men's comfort").

${ }^{205}$ See Cynthia G. Bowman, Street Harassment and the Informal Ghettoization of Women, 106 HARV. L. REV. 517, 519-22 (1993) (arguing that the law should recognize the harm of street harassment and provide an effective remedy); see also HAYDEN, REDESIGNING THE AMERICAN DREAM, supra note 48, at 217-21 (describing the daily commute of two working women on public transportation, a journey which takes "them through an urban landscape filled with images of men as sexual aggressors" on billboards, bus placards, and so on).

${ }^{206}$ See Alice KeSSLER-HARRIS, OUT TO WORK: A HistoRY OF WAGE-EARNING WOMEN IN THE UNITED STATES 304-19 (1982).

${ }^{207}$ See Natalie M. Hanlon, Note, Child Care Linkage: Addressing Child Care Needs Through Land Use Planning, 26 HARV. J. ON LEGIS. 591, $592-98$ (1989) (discussing various legislative proposals that require developers to consider the need for 
developers incentives, such as additional square footage, in exchange for on-site child-care facilities. ${ }^{208}$ Other techniques include adding child care as an optional element to a community's general plan, much as historical preservation or recreational space has been added, or modifying an existing plan to include directives favorable to child care. ${ }^{209}$ For example, Palo Alto, California amended its Comprehensive Plan in 1981 to "[s]upport the use of variances where appropriate to expand site coverage in industrial zones for child care facilities.

Thus over a fifty-year period, from 1945 to the present, there has been a gradual reconceptualization of the relationship between a mother's physical environment and her maternal duties. Few women now have the option to excel in stay-at-home motherhood,

convenient child care in connection with their building projects).

${ }^{208}$ See Planning for ChIld CARE: A COMPENDIUM For CHILd CARE Advocates SEEkING THE INCLUSION OF CHILd CARE IN THE LAND USE/DEvelopMENT PROCESS at VI-1 to VI-6 (Abby J. Cohen ed., 1987).

${ }^{209}$ See id. at II-3.

${ }^{210} \mathrm{Id}$. The relationship among child care, the demands of modern life, and the law is hinted at in what may seem an unlikely source: the school desegregation plans of the 1980s. Limited in their ability to order the desegregation of school systems across district lines, school boards have turned to what has been called "desegregation by carrot"-schools so delicious that no right-minded (white) parent would consider moving to the suburbs just "for the schools." See Hamil R. Harris, Will Magnets Have Pull Here? Smith Aims to Repeat Dayton Success Story, WASH. PoST, Apr. 1, 1993, at D.C.I.

The hope is that such [enrichment] programs will attract some of the more than 12,000 white school-aged children in the District [of Columbia] who now attend private or parochial schools.

....

"We took a representative sample" and asked what it would take to get them to place their child in a D.C. school, said magnet coordinator Joan Brown.

Id. at D.C.1, D.C.7; see also Stephen Hegarty, Magnet Schools Highly Popular, ST. PeTERSBuRG TIMES, Mar. 14, 1993, at 1 (noting the success of magnet schools in Hillsborough County, Florida); Robert E. Pierre, Magnet Program Expanding: 4 More Schools Will Start Special Classes in Fall, WASH. POST, Jan. 28, 1993, at Md.1 (discussing magnet school programs in Prince George's County, Maryland, a suburb of Washington, D.C. with a large black population). The principal mechanism used to accomplish voluntary desegregation is the "magnet school," a public city school sufficiently enriched in curriculum and resources that it can compete for students with suburban school districts. Among the features that city school boards have determined are likely to persuade parents to keep their children in city schools (besides theme schools, multicultural curricula, and bilingual classes) are all-day programs which allow working parents to fulfill their duties (making sure their child is occupied after school) without compromising their own work schedules. 
and many are beginning to look to resources beyond themselves and their station wagons for solutions. ${ }^{211}$

The physical and functional structure of suburban space has confined women in dream towns from which many occupants are now awakening. The purchase and maintenance of single-family homes and all they stand for are expenses that few families can manage. Consumer demand by such groups as the elderly has caused land-use planners and architects to come up with more communal, cooperative ways of living, featuring common kitchens and recreation areas, smaller lawns, and proximity to public transportation. Many of these "innovations," the stuff of women's architecture for the last hundred years, are appropriate for modern families, in their varied new formations.

In consequence, the demand that shops, child care facilities, doctors, and transportation be located and designed in response to the needs of working women and working men seems the next practical step. One possibility is for women and their families to shut down the suburbs and return to the city, by definition a place where services are more concentrated and public transportation more available. ${ }^{212}$ Yet many prefer the expanses of air and space suburban life still provides and would reclaim rather than shut down the enterprise. This does not mean jettisoning our cars en masse, especially just as women are catching on to a variety of automotive pleasures. What goes out, however, is the role-subordination that was so cleverly captured by the socialized use of cars.

With all this in mind, I want to end with a different image of women and cars than the oppressive and perilous ones I have presented here. A 1992 New Yorker article recounted the trip of several young women who drove from New York to Washington, D.C. to join some 500,000 others for the March for Reproductive Freedom. The author describes their return trip:

They made several stops along the way, and Melissa told me that she felt a thrill when she noticed that every Burger King, every Taco Bell, every gas station was filled with women. The Washington Post reported that three-quarters of the marchers had been

${ }^{211}$ See supra notes 52-53 and accompanying text.

${ }^{212}$ See Jerry Frug, The Geography of Communily, 48 STAN. L. REV. (forthcoming 1996) (manuscript at 96, on file with author) (noting that "feminist urban theorists object not only to the practical problems that this [suburban] isolation has created but also, more fundamentally, to the privatized, sheltered idea of women's lives embodied in suburban design"). 
female. That night, it must have seemed as though there were only women on the road..$^{213}$

${ }^{213}$ The Talk of the Town, NEw YORKER, Apr. 27, 1992, at 29, 30. 